INVITED REVIEW

100 YEARS OF INSULIN

\title{
Pancreas pathology in type 1 diabetes: an evolving story
}

\author{
Sarah J Richardson ${ }^{1}$ and Alberto Pugliese ${ }^{2}$ \\ ${ }^{1}$ Islet Biology Group, Exeter Centre for Excellence in Diabetes (EXCEED), Institute of Biomedical and Clinical Sciences (IBCS), University of Exeter, RILD Level 4, \\ Exeter, UK \\ 2Division of Diabetes Endocrinology and Metabolism, Departments of Medicine, Microbiology and Immunology, Diabetes Research Institute, Leonard \\ Miller School of Medicine, University of Miami, Miami, Florida, USA
}

Correspondence should be addressed to A Pugliese: apuglies@med.miami.edu

This paper forms part of a special section on 100 years of insulin. The guest editors for this section were James Cantley \& Decio Eizirik.

\begin{abstract}
We review the current knowledge of pancreas pathology in type 1 diabetes. During the last two decades, dedicated efforts toward the recovery of pancreas from deceased patients with type 1 diabetes have promoted significant advances in the characterization of the pathological changes associated with this condition. The implementation of autoantibody screening among organ donors has also allowed examining pancreas pathology in the absence of clinical disease, but in the presence of serological markers of autoimmunity. The assessment of key features of pancreas pathology across various disease stages allows driving parallels with clinical disease stages. The main pathological abnormalities observed in the pancreas with type 1 diabetes are beta-cell loss and insulitis; more recently, hyperexpression of HLA class I and class II molecules have been reproduced and validated. Additionally, there are changes affecting extracellular matrix components, evidence of viral infections, inflammation, and ER stress, which could contribute to beta-cell dysfunction and the stimulation of apoptosis and autoimmunity. The increasing appreciation that beta-cell loss can be less severe at diagnosis than previously estimated, the coexistence of beta-cell dysfunction, and the persistence of key features of pancreas pathology for years after diagnosis impact the perception of the dynamics of this chronic process. The emerging information is helping the identification of novel therapeutic targets and has implications for the design of clinical trials.
\end{abstract}

\author{
Key Words \\ - type 1 diabetes \\ - insulitis \\ - beta cell \\ - pancreas \\ - islet autoimmunity
}

\section{Introduction}

Type 1 diabetes (T1D) is a chronic disease characterized by severe loss of insulin secretion, requiring insulin replacement therapy for the individual's lifetime. The disease is often diagnosed in children and adolescents, but approximately $40 \%$ of patients develop T1D as adults (Maahs et al. 2010, Thomas et al. 2018).
Symptoms often present acutely, especially in children, and can potentially lead to life-threatening complications. However, longitudinal natural history studies in the relatives of patients and in newborns at increased genetic risk have revealed that critical pathogenic mechanisms are triggered months to years before clinical diagnosis. These 


\section{Journal of Endocrinology}

culminate in the progressive dysfunction of pancreatic beta cells and their autoimmune destruction. A variety of mechanisms are believed to cause T1D, which could explain the significant heterogeneity in its clinical severity and pathological features. The mechanisms of disease may not be necessarily active in every patient; even in a single patient, these may vary with disease stage. This article will describe the current state of knowledge about the pancreas pathology observed in T1D across its natural history, and we will integrate the interpretation of pathology findings with clinical data. There has been much progress in both research areas in the last decade, given the activities of clinical consortia, improved access to pancreas specimens obtained from organ donors with T1D at various stages of disease progression, and the parallel implementation of novel methodologies to assess pathology as well as immunological and metabolic parameters in the circulation. While many unknowns remain, significant progress has been made which impacts our understanding of disease pathogenesis and heterogeneity, and guides strategies for prevention and treatment in clinical trials.

\section{Access to the pancreas with type 1 diabetes}

A major obstacle to understanding the pathogenesis of T1D is that the pancreas, the target organ, is not easily accessible. However, beginning in the 1950s, scientists began to examine the pancreas from deceased patients. Initially, such pancreases were obtained at autopsy, often near the time of a diagnosis reflecting a higher probability of passing following acute complications of ketoacidosis. This was largely through the effort of individual investigators. Advances in the treatment of diabetes mean that such deaths have progressively declined, and pancreas recoveries have become more sporadic in nature. Later, limited efforts involved the collection of pancreas tissue using percutaneous or laparoscopic biopsies. More recently, a number of well-organized efforts are actively obtaining pancreases from T1D patients who have passed, as organ donors. We describe below the major efforts that have, or are, obtaining pancreas tissue from patients, from which important observations have been and continue to be made (Fig. 1):

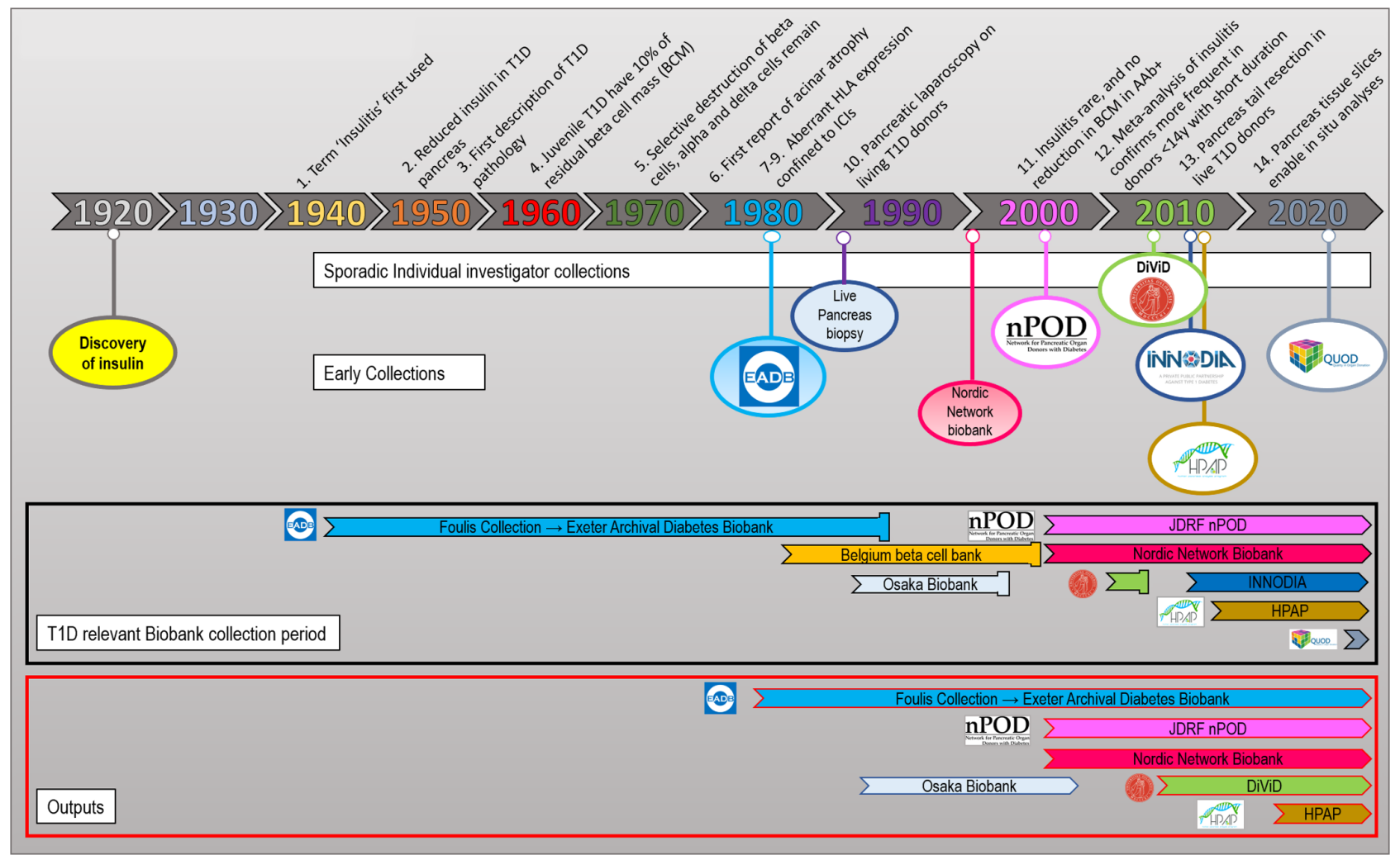

Figure 1

Seminal pathology observations and collections from the last 100 years illustrated within a timeline. The key observations and references are described in more detail in Table 2. The timeline of key T1D-relevant biobanks that have been established are represented by the colored circles with biobank description. The T1D-relevant biobank collection periods for each biobank are illustrated in the black box, with the timelines of scientific outputs for each biobank illustrated in the red box. 


\section{Collections of autoptic pancreata}

Following initial studies of autoptic pancreata from the 1950s-1960s (Lecompte 1958, Gepts 1965), in the 1980s, Foulis implemented a systematic collection of autopsy pancreas in the UK. Now known as the Exeter Archival Diabetes Biobank (EADB, https://foulis.vub.ac.be), the collection consists of formalin-fixed, paraffin-embedded pancreas blocks. The EADB is the world's largest collection of autopsy pancreas samples recovered near a diagnosis of T1D reflecting the higher probability of patients passing away because of acute complications of ketoacidosis, between 1945 and the 1990s, when these autopsies were performed (Gepts 1965, Gepts \& De Mey 1978, Foulis et al. 1986). Thankfully, deaths have become progressively rarer with improved therapeutic management of hyperglycemia and ketoacidosis. The EADB holds specimens from about 200 patients, of which 100 are from <20-year-old patients with recent-onset T1D.

\section{Pancreas biopsy collections}

In the early 1990s, investigators obtained limited amounts of the pancreas from 18 T1D patients in Japan via percutaneous biopsies (Hanafusa et al. 1990, Itoh et al. 1993). In the 2010s, the Diabetes Virus Detection study (DiViD, https://www.oslodiabetes.no/diabetesvirus-detection-study-divid) obtained larger specimens via laparoscopic pancreatic tail resection from six living adults (24-35 years old) with recent-onset T1D (Krogvold et al. 2014). Given the surgical complications experienced in this study, the biopsy approach has not been used since 2014 (Atkinson 2014). However, the samples obtained were shared with many investigators worldwide for collaborative studies and yielded important information.

\section{Organ donors}

Significant efforts have since been launched to collect and study pancreata obtained from organ donors more systematically. Starting in 1989, the Islet Transplantation Program in Belgium (In't Veld et al. 2007) and the Nordic Network for Islet Transplantation (Sweden 2007-2015) (Wiberg et al. 2015) screened organ donors for T1Dassociated autoantibodies, to identify those with preclinical disease and to ascertain the possible presence of early prediagnostic pathological alterations. As these pancreata were processed for islet isolation, although only limited amounts of whole pancreas tissue were obtained for histopathology, important information was nevertheless obtained, as described later in this review. The Belgium program screened 1507 organ donors aged 25-60 years (Wiberg et al. 2015) and 556 donors younger than 25 years of age (Smeets et al. 2021); autoantibody positivity was found in $62(4.1 \%)$ and in $27(4.8 \%)$ of these donors, respectively. Most donors (7/62 and 25/27) expressed a single autoantibody, and the most prevalent single autoantibody was directed against the GAD65 autoantigen. The Nordic Network for Islet Transplantation screened 969 non-diabetic organ donors and identified 32 (3.3\%, age range 21-74 years) autoantibody-positive donors, all expressing GAD autoantibodies, of which three also had antibodies to the autoantigen IA-2.

Beginning in 2007, the Network for Pancreatic Organ Donors with Diabetes (nPOD, www.JDRFnPOD.org) (Pugliese et al. 2014), launched an autoantibody screening of organ donors in the United States; at the time of writing, pancreata from 48 autoantibody-positive donors have been obtained, of whom 14 had multiple autoantibodies. nPOD actively recovers pancreata from organ donors with T1D, as well as autoantibody-negative organ donors without diabetes (control). nPOD has so far identified 188 donors with T1D and 233 control donors. The T1D cohort includes donors with disease duration $<1$ year $(n=13)$, 1-5 years $(n=35), 5-10$ years $(n=37)$, and $>10$ years $(n=99)$. In addition to frozen and fixed pancreas specimens, nPOD obtains other disease-relevant tissues (lymph nodes, spleen, thymus, duodenum, blood, and more recently, kidney). Specimens are made available to scientists worldwide and include fixed/frozen tissues and live cells. nPOD has also recently developed means for distributing live cells and tissues, including isolated islets and pancreas slices (Panzer et al. 2020, Qadir et al. 2020).

Partnering with nPOD, the Human Islet Research Network has launched the Human Pancreas Analysis Program (https://hpap.pcmacs.upenn.edu), which since inception has studied pancreas from 22 organ donors with T1D and 16 autoantibody-positive donors, 14 with a single autoantibody (13/14 with GAD autoantibodies) and 2 with multiple autoantibodies. The INNODIA consortium in Europe (https://www.innodia.eu) and the Quality in Organ Donation (https://quod.org.uk) in the UK have recently begun collecting pancreas from organ donors with T1D.

The increasing access to T1D pancreas from a broader spectrum of disease stages, age and disease duration ranges, the availability of additional tissues besides pancreas, the study of live tissues and cells, and the application of the latest technologies are all contributing to dramatic progress. This has evolved our understanding of pancreas pathology, and in turn, the pathogenesis of T1D, well 
beyond what we had learned from the initial studies limited to histopathology analyses.

\section{Key features of pancreas pathology in T1D}

The major features of pancreas pathology have been traditionally considered to be a marked loss of beta cells and the presence of lymphocytic infiltrates in the pancreatic islets, or insulitis, which were initially reported in the mid1960s. Much progress has been made in the characterization and quantification of these phenomena throughout the natural history of the disease. It has also been recognized that age-at-onset, and disease stage and time are major determinants of these features. The hyperexpression of HLA class I molecules in islets and the aberrant expression of HLA class II molecules by beta cells were initially reported in the mid-1980s, yet were not fully accepted until very recently, when, taking advantage of novel technologies, multiple biobanks, and islet cells isolated from donors with T1D, these findings were confirmed and further expanded. The additional features that were reported in recent years include critical alterations of extracellular matrix components, evidence of exocrine abnormalities and inflammation (Campbell-Thompson et al. 2015), rare donors with evidence of amyloid deposition (Westermark et al. 2017, Denroche \& Verchere 2018, Beery et al. 2019), and multidisciplinary evidence for viral infections (Dunne et al. 2019, Apaolaza et al. 2021, Geravandi et al. 2021). Thus, our understanding of pancreas pathology and associated molecular changes has evolved over time, and our knowledge is now more comprehensive. We will now describe the traditional pancreas pathology features and the more recently established alterations and discuss their significance in the disease pathogenesis, with attention to the disease stage at which they are observed.

As noted, the characterization of pancreas pathology in patients with T1D began in the late 1950s, with reports from LeCompte (1958) and Gepts (1965), who first described the two main pathology features, betacell loss and insulitis. Gepts evaluated the pancreas from 22 young children who had passed soon after diagnosis ( $<3$ months for 21) and observed severe loss of beta cells. Residual beta cells exhibited cytological signs of marked activity, and large islets and signs of new islet formation were noted. There were peri- and intra-islet inflammatory infiltrates, or insulitis lesions. Insulitis was not observed in the pancreas of 18 donors with a longer disease duration, in whom all beta cells were virtually lost. Another major observation was the expression of elevated levels of HLA class I molecules by islet cells, first reported by Bottazzo and Foulis in the mid-1980s (Bottazzo et al. 1985, PujolBorrell et al. 1986, Foulis et al. 1987).

\section{Insulitis}

This lesion consists of immune cells infiltrating the pancreatic islets (In't Veld 2011) and it represents pathological evidence of the immune-mediated destruction of pancreatic beta cells. Islet-infiltrating immune cells are more commonly detected in the islet periphery (peri-insulitis), and the presence of inflammatory cells within the islets is considered an expression of increased disease severity in that islet. In the pancreas with T1D, the prevalence of insulitis is affected by age and time since diagnosis. In the mid-1980s, Foulis et al. (1986) observed that most (78\%) young patients with recent-onset disease ( $<1$ year) had insulitis. In 2011, In't Veld (2011) reported a meta-analysis of studies published since 1902, which overall described insulitis in 213 cases. In this meta-analysis, most young ( $<14$ years) T1D patients within one month of diagnosis had insulitis, but insulitis was observed in only $4 \%$ of patients who had had T1D for more than one year. Among patients diagnosed between 15 and 40 years of age, insulitis was reported in only $29 \%$ of those with T1D duration $<1$ month. Thus, insulitis appears to be more evident in younger patients, possibly representing an age at which the disease has greater severity, a concept also supported by studies in clinical cohorts (Krischer et al. 2021).

Another important notion is that insulitis is predominantly found in islets that contain beta cells; insulin-negative, or 'pseudo-atrophic' islets rarely show insulitis. In the meta-analysis by In't Veld (2011) involving young patients with recent-onset disease ( $<1$ month), on average $34 \%$ of the islets stained for insulin, but only $33.6 \%$ of these islets had insulitis; in older patients with recent-onset disease, an increased proportion of islets contained beta cells (63\%), with only $18 \%$ of these insulincontaining islets (ICIs) showing insulitis. Foulis (Willcox et al. 2009) reported insulitis in $23 \%$ of ICIs and only $1 \%$ in insulin-deficient islets (IDIs) in young patients with $<1$ year duration of T1D. Willcox et al. reported 23.8\% of ICIs, of which $34.8 \%$ had insulitis, among 29 young patients diagnosed within the preceding 18 months. In comparison, insulitis was seen in only $5 \%$ of the IDIs. In the DiViD study, which obtained pancreas tail biopsies from six adult patients near diagnosis, an average of $11 \%$ of the islets had insulitis, and a single patient had insulitis in more than 50\% of the islets (Krogvold et al. 2014, 2016). 
An nPOD study of organ donors with variable T1D duration (0-12 years) reported 17 donors with insulitis in whom there was a limited inverse correlation with disease duration and no correlation with age, whether age at diagnosis or age at passing. This may reflect the limited size of the cohort and the broad range of age and disease duration. Taken as a whole, these studies suggest that the proportion of islets with insulitis at any given time is moderate to low, particularly in those diagnosed in their teens and beyond, and it is impacted by age and disease duration. Moreover, more recent studies investigated insulitis in pancreata obtained years after diagnosis (Campbell-Thompson et al. 2016a), and this can be observed usually within the first decade, supporting the chronic nature of islet autoimmunity.

A variety of immune cells are observed in insulitis lesions, including $\mathrm{T}$ and $\mathrm{B}$ lymphocytes, macrophages, and less frequently, natural killer cells (Dotta et al. 2007, Willcox et al. 2009). A consensus definition of insulitis was published in 2013 (Campbell-Thompson et al. 2013), and describes insulitis as a predominantly lymphocytic infiltration of the islets with minimum 15 CD45-positive cells/islet, to be present in at least 3 islets, along with the presence of pseudo-atrophic islets. It has been debated whether a revised definition of insulitis should be based exclusively on CD3-positive T cells (Campbell-Thompson et al. 2017, Lundberg et al. 2017a,b). Cytotoxic CD8 T cells are the predominant population; using class I tetramers, nPOD investigators showed that islet-infiltrating CD8+ $\mathrm{T}$ cells are autoreactive toward known beta-cell autoantigens (Coppieters et al. 2012, Bender et al. 2020). Increasing disease duration was associated with higher diversity in the antigen specificity of the infiltrating CD8 T cells, suggesting epitope spreading even after the clinical diagnosis.

Differences in the cellular composition of the insulitis lesions have been described. Lesions which are more extensive and enriched in B lymphocytes are more often observed in children younger than 12 years of age, and those pancreata show more severe beta-cell loss than older children with insulitis lesions containing fewer infiltrating cells and fewer B lymphocytes (Leete et al. 2016). These findings suggest that in younger children, B lymphocytes may contribute to more aggressive islet autoimmunity (Leete et al. 2016, Morgan 2017) and represent an example of disease endotypes that define disease heterogeneity and possibly guide therapeutic choices (Battaglia et al. 2020), considering that that inflamed islets within a given patient have the same insulitis profile in terms of B-lymphocyte abundance (Leete et al. 2016).

\section{Beta-cell loss and dysfunction}

Once T1D has been clinically diagnosed, the predominant pathological feature in the T1D pancreas is severe loss of beta cells. However, the long-held belief that $90 \%$ of the beta-cell mass is lost by the time of clinical of diagnosis does not appear correct for every patient, based on review of earlier data (Klinke 2008, 2011) and on more recent studies (Campbell-Thompson et al. 2016a, Krogvold et al. 2016, Leete et al. 2016). It is now emerging that the severity of beta-cell loss varies in relationship with age and disease duration. The pancreas of younger children typically displays the more severe beta-cell loss, but those diagnosed when in their teenage years or later may have $40-60 \%$ of their islets staining positive for insulin (Klinke 2008, Leete et al. 2016), based on recent analyses from the DiViD, EADB, and nPOD cohorts (Campbell-Thompson et al. 2016a, Krogvold et al. 2016, Leete et al. 2016). The six DiViD biopsies obtained from adult patients at diagnosis demonstrated insulin staining on average in 36\% (18-66\%) of the islets examined (Krogvold et al. 2016).

Because pathology studies show significant variability in actual beta cell loss, there appears to be an important role for beta cell dysfunction. The relative proportions of beta-cell loss and dysfunction may vary by age group and other individual factors. The functional assessments of insulin secretion in living patients concur with these pathology findings to a reasonable extent. At diagnosis, insulin secretion is severely impaired, and the severity of impaired insulin secretion is greater in younger age groups (Sherry et al. 2005, Tsai et al. 2006, Greenbaum et al. 2009, 2012, Sherr et al. 2014); however, many patients have clinically meaningful residual insulin secretion (Sherry et al. 2005, Tsai et al. 2006, Greenbaum et al. 2009, 2012, Sherr et al. 2014, Hao et al. 2016) exceeding a stimulated C-peptide level of $0.60 \mathrm{ng} / \mathrm{mL}(0.2 \mathrm{pmol} / \mathrm{mL})$, which is associated with better metabolic control and reduced risk of complications (Steffes et al. 2003, Flatt et al. 2021, Jeyam et al. 2021). Longitudinal studies that included both pre- and post-diagnostic evaluation of insulin secretion revealed that the progressive loss of insulin secretion is more pronounced during the 6-month intervals that precede and follow diagnosis (Bogun et al. 2020). This may suggest heightened activity of the underlying disease mechanisms, which is consistent with the more pronounced prevalence of insulitis around the time of diagnosis. Beta-cell mass becomes more severe with increasing disease duration. The progression of beta-cell destruction varies among individuals, it does not occur simultaneously for all islets, and chronic autoimmune destruction may continue for 
a few years after clinical diagnosis. Moreover, at least in some patients, insulin-positive beta cells may persist even decades after diagnosis (Meier et al. 2005a,b, Gianani et al. 2010, Keenan et al. 2010). Several studies have reported that patients with long disease duration may secrete low amounts of C-peptide and also respond with increased levels to stimulation (Keenan et al. 2010, Wang et al. 2012, Oram etal. 2014, 2015). However, the clinical impact of these residual beta cells may be minimal, and they may exhibit apoptosis (Meier et al. 2005a,b, Keenan et al. 2010) and signs of inflammation (insulitis, hyperexpression of HLA class I molecules (Morgan et al. 2014)). Overall, pathology and clinical studies suggest that T1D is caused by a chronic disease process which affects islets asynchronously, and continues its course over a long period of time after diagnosis (Table 1).

\section{Hyperexpression of HLA class I molecules by islet cells}

Another key feature of pancreas pathology in T1D is the presence of elevated levels of HLA class I molecules in islet cells; this finding supports the concept that islets are inflamed (Morgan et al. 2014). Hyperexpression of HLA class I molecules was reported initially in the mid1980s (Foulis et al. 1987); it has recently been replicated and extended beyond its demonstration by immunohistochemistry (Richardson et al. 2016). HLA class I hyperexpression is typically associated with ICIs and the presence of CD8 T-cell infiltrates, suggesting that beta cells may be presenting autoantigens to autoreactive CD8 T cells. However, ICIs can hyperexpress HLA class I with no detectable immune cell infiltration present (Foulis et al. 1987b), suggesting that factors independent of the immune cells can drive hyperexpression. It is also plausible that viral infections associated with T1D may induce hyperexpression of class I molecules (Richardson et al. 2009, Krogvold et al. 2015a), but it remains to be determined whether islet-infiltrating CD8 T cells may also target viral epitopes presented by infected beta-cells (Kundu et al. 2018). Like insulitis, class I HLA hyperexpression can be observed in the pancreas even years after diagnosis (Coppieters et al. 2012, Richardson et al. 2016) in islets that contain residual beta cells. HLA class I hyperexpression has been correlated with the rate of beta-cell destruction (Shields et al. 2018). There is evidence that HLA I hyperexpression is also present in pancreatic islets of nPOD donors without diabetes, who however expressed T1D-associated autoantibodies even in the absence of insulitis (Benkahla et al. 2021). HLA class I molecules are mostly expressed by alpha cells, but also beta cells, on the cell surface, and also accumulate intracellularly in the Golgi apparatus. Thus, while hyperexpression of HLA class I may represent an inflammatory response and may facilitate presentation of self/viral epitopes to CD8 T cells, it may also contribute to islet dysfunction by disrupting intracellular trafficking and may affect both alpha and beta cells.

\section{Endotypes}

Differences in pathology and clinical features among patients support the concept of the disease endotypes in which these phenotypes may reflect disease heterogeneity in the pathogenesis and clinical course, which may also be relevant to treatment (Arif et al. 2014, Battaglia et al. 2020, Leete et al. 2020). In pancreas pathology, the major features distinguishing endotypes are the intensity of the immune infiltration, the cellular composition of islet infiltrates, the degree of beta cell destruction, and the processing/ localization of proinsulin. Pancreas pathology studies involving specimens from the EADB led to the proposal of two T1D endotypes in children and young adults, named T1D endotype 1 and 2, or T1DE1 and T1DE2, respectively. T1DE1 is associated with younger age of onset (typically $<7$ years), a more aggressive immune attack with an increased frequency of CD20+ B lymphocytes within islet infiltrates,

Table 1 Presence of key pathology features in the T1D pancreas across the natural history of the disease.

\begin{tabular}{|c|c|c|c|c|c|}
\hline & Single $\mathbf{A A b}$ & Multiple AAb (Stage 1 T1D)* & T1D onset & $0-10$ years T1D duration & $>10$ years T1D duration \\
\hline Beta-cell loss & - & + & ++ & +++ & ++++ \\
\hline Insulitis & - & + & +++ & ++ & - \\
\hline Increased HLA I & Rare & + & +++ & ++ & - \\
\hline Viral Infection Markers & $+/-$ & + & ++ & ++ & - \\
\hline
\end{tabular}

The table illustrates how selected features of pancreatic pathology are more or less represented, depending on disease stage, using a simple scale. It appears that features such as insulitis, beta-cell loss, hyperexpression of HLA class I molecules, and markers of viral infection are rare at the stage of single autoantibody positivity. All features become detectable at stage 1 (T1D), and are more prominent at onset and afterward for several years after onset. Beta-cell loss is the only feature that remains beyond a decade after onset. Note that these are exemplifications and there is significant individual variation, determined by a variety of factors, including age, genetic and environmental determinants.

*There are no reported studies of the pancreas from donors with stage 2 T1D.

https://joe.bioscientifica.com

https://doi.org/10.1530/JOE-21-0358 (c) 2021 Society for Endocrinology Published by Bioscientifica Ltd. Printed in Great Britain 
fewer residual beta cells, and evidence of impaired proinsulin hormone processing within the remaining beta cells. In these patients, proinsulin is found in mature granules, colocalizing with the processed insulin. Similar observations in terms of proinsulin were made in the nPOD cohort (Wasserfall et al. 2017, Sims et al. 2019). This is also consistent with elevated proinsulin:C-peptide ratio described in children during progression to clinical T1D (Sims et al. 2016). One might assume, therefore, that following stimulation, increased levels of proinsulin will be released in combination with insulin in the T1DE1 individuals, a phenomenon that appears to bear out when also examining the proinsulin:C-peptide ratio in the blood of individuals $<10$ years of T1D duration. In contrast, T1DE2 is associated with an older age-at-onset ( $\geq 13$ years), a less aggressive immune attack with very few or no CD20+ B lymphocytes within the infiltrate, and the retention of a significant number of beta cells. Although insulin appears to be processed normally in these beta cells, it may be that it is not being released appropriately. Individuals diagnosed between 7 and 12 years can be defined as either T1DE1 or T1DE2 through the examination of the immune profile and localization of proinsulin. The field is advancing the characterization of endotypes through a combination of integrated assessments, including genetic, immunological and metabolic, at both the pathology and the clinical levels.

\section{Additional pathology features of the T1D pancreas}

Additional pancreatic pathological abnormalities have been described and appear to contribute to the disease pathogenesis.

\section{Inflammation, beta cell stress, and dysfunction}

Islet inflammation induces stress, protein misfolding, dysfunction, and apoptosis in beta cells (Fu et al. 2013, Marroqui et al. 2015, Brozzi \& Eizirik 2016, de Beeck \& Eizirik 2016). Residual beta cells in the T1D pancreas show evidence of stress, including increased expression of endoplasmic reticulum stress markers (Marhfour et al. 2012, Eizirik \& Coomans de Brachène 2017, Marroqui et al. 2017, Eizirik \& Colli 2020); these are particularly evident in infiltrated ICIs (Marhfour etal. 2012, Eizirik etal. 2013). Betacell stress may lead to the generation of post-translationally modified and hybrid autoantigens which could represent critical targets of islet autoimmune responses (Marre et al. 2015). For example, endoplasmic reticulum stress leads to the accumulation of an immunogenic, palmitoylated form of this GAD65 autoantigen in trans-Golgi membranes of beta cells (Phelps et al. 2016). Chronic inflammation and endoplasmic reticulum stress could all be important mediators of beta-cell dysfunction (Marhfour et al. 2012,

Table 2 Key observations and references.

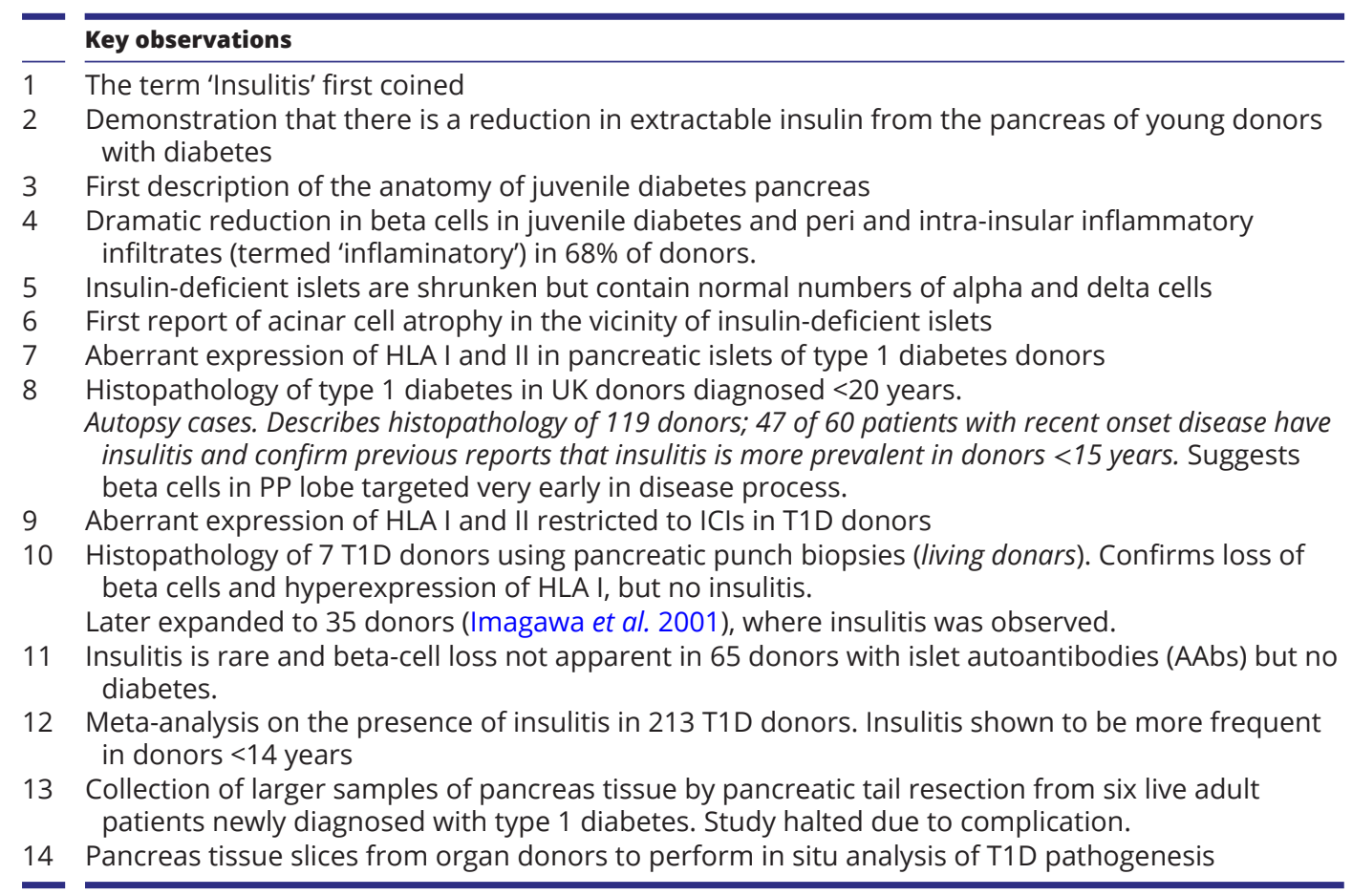

\section{Reference \\ von Meyenberg 1940 \\ Wrenshall et al. 1952 \\ Lecompte 1958 \\ Gepts 1965}

Gepts and De Mey 1978

Foulis and Stewart 1984

Bottazzo et al. 1985

Foulis et al. 1986

Foulis et al. 1987

Hanafusa et al. 1990

Imagawa et al. 2001

In't Veld et al. 2007

In't Veld 2011

Krogvold et al. 2014

Panzer et al. 2020 
Burch et al. 2015, Grzesik et al. 2015, Krogvold et al. 2015b, Imai et al. 2016), which contributes to insulin secretion abnormalities during the prediabetic phase and after diagnosis (Ludvigsson \& Heding 1982, Heaton et al. 1988, Røder et al. 1994, Truyen et al. 2005, Van Dalem et al. 2016, Sims et al. 2016, 2018, 2019, Evans-Molina et al. 2018). As noted above, evidence of dysfunction is exemplified by abnormalities in the processing of the proinsulin prohormone to mature insulin, which has been observed in pancreas pathology studies of nPOD donors (Wasserfall et al. 2017, Rodriguez-Calvo et al. 2021): compared to controls, immunostaining of about $50 \%$ of insulinpositive T1D donors revealed increased proportions of proinsulin-enriched, insulin-poor beta cells with reduced mRNA levels of the proinsulin processing enzymes prohormone convertase 1/3 (PC1/3) and carboxypeptidase $\mathrm{E}$ (CPE). Experimentally, inflammatory cytokines reduced mRNA expression of PC1/3, PC2, and CPE in human islet cells. Of note, proinsulin processing was also inhibited by reduction of PC2 following persistent infection of the Ins-1 beta-cell line with Coxsackie B virus (Nekoua et al. 2021). Taken together, alterations of proinsulin processing appear linked to multiple disease mechanisms and represent a critical aspect of beta-cell dysfunction in T1D. It is possible that islet dysfunction may be corrected, as shown in vitro by the DiViD study (Krogvold et al. 2015b), where islets isolated from the biopsied pancreases recovered function in culture. The recognition of beta-cell dysfunction, especially at diagnosis, implies that therapeutic strategies should include interventions that restore and support betacell function. The overall modest prevalence of insulitis at any given time suggests that the benefit of immunotherapy may be limited to those islets with insulitis and limit overall treatment efficacy. Combinatorial therapies should therefore address pathogenic cofactors, attempt to mitigate inflammation, and correct beta-cell dysfunction (Skyler 2015).

\section{Aberrant expression of HLA class II molecules by beta cells}

Another early observation is the aberrant expression of HLA-II molecules by beta cells, initially reported in in $22 / 26$ and in 6/12 pancreata from patients with recentonset and long-standing disease, respectively (Bottazzo et al. 1985, Foulis et al. 1987, Lernmark et al. 1995). Like HLA class I molecules, the class II molecules may be upregulated by viruses linked to T1D (Krogvold et al. 2015a, Hyoty 2016) and by inflammatory cytokines such as IFN- $\gamma$ plus TNF- $\alpha$ or lymphotoxin, which were shown to induce
HLA I/II molecules on beta cells experimentally (PujolBorrell et al. 1987, Campbell et al. 1988). More recently, the observation of aberrant expression of HLA class II molecules has been reproduced using a variety of advanced methodologies such as transcriptome analysis of bulksorted and single beta cells (Russell et al. 2019): transcripts for HLA class II and other molecules in the class II antigen presentation pathway were demonstrated in cells lacking the macrophage marker CD68; this is important because macrophages that had captured dying beta cells had been considered as the explanation for this phenomenon. Immunohistology of pancreas sections from donors with recent-onset T1D from three independent cohorts demonstrated HLA class II antigens and the class II transactivator protein in CD68-negative, insulin-positive beta cells, and were found in islets with insulitis. Finally, beta cells were shown to express HLA class II molecules on their surface, by flow cytometry. Thus, the expression of HLA class II molecules by beta cells has now been validated. This suggests that beta cells may interact directly with isletinfiltrating CD4+ T cells, as originally proposed by Bottazzo in the mid-1980s (Bottazzo 1986).

\section{PDL1 expression by beta cells}

Another example of interactions between beta cells and infiltrating $\mathrm{T}$ cells derives from studies demonstrating that the programmed death-ligand 1 (PDL1) can be expressed in insulin-positive beta cells in the T1D pancreas, but not in IDIs or in control pancreas (Colli et al. 2018, Osum et al. 2018). PDL1 expression in beta cells has been linked to interferon alpha and gamma, in the context of alterations induced by islet inflammation, and is likely to represent a defense mechanism against autoreactive T cells expressing the PD1 receptor (Colli et al. 2020).

\section{Alterations of extracellular matrix components}

Hyaluronan (HA), a key constituent of the extracellular matrix, and HA-binding proteins, deposit around islet cells and infiltrating lymphocytes in islets affected by insulitis (Bogdani et al. 2014a). Hyaluronan deposition is found along intra-islet micro-vessels and the edge capillaries of the islets, near infiltrating lymphocytes; it is more evident in younger donors with T1D and within the first year from diagnosis, suggesting a link to the disease pathogenesis (Bogdani et al. 2014a). Similar alterations were reported among nPOD donors with autoantibodies (Bogdani et al. 2020): abundant HA deposits were observed in pancreatic islets from donors with single and multiple 
autoantibodies, even in the absence of insulitis. Thus, HA may form a matrix that may favor lymphocytic infiltration of the islets (Bogdani 2016) and promote an inflammatory milieu (Nagy et al. 2015, Kuipers et al. 2016). Other studies have noted loss of laminin, perlecan, and collagen, critical components of the peri-islet basal membrane, in islets with insulitis (Korpos et al. 2013), suggesting that the removal of the basal membrane is associated with islet infiltration by inflammatory leukocytes, where its degradation appears to be mediated by cathepsins (Korpos et al. 2013). Moreover, islet cell loss of heparan sulfate has been associated with impaired beta-cell function and survival, as it promotes beta-cell apoptosis (Bogdani et al. 2014b, Simeonovic et al. 2018).

\section{Tertiary lymphoid organs (TLOs)}

Recent studies of extracellular matrix components have led to the observation that another feature of pancreas pathology is the formation of tertiary lymphoid organs (TLOs). First described in NOD mice pancreas (Penaranda et al. 2010), TLOs were demonstrated in the human pancreas among donors without diabetes expressing multiple autoantibodies, among patients with T1D, and in the transplanted pancreas with demonstrated recurrence of islet autoimmunity (Korpos et al. 2021). Several features of the TLOs in the human pancreas were shared with NOD mice, such as the cellular and ECM composition of reticular fibers, the presence of high endothelial venules, and immune cell subtypes detected. Importantly, compartmentalized TLOs with distinct T-cell and B-cell zones were detected in younger donors with shorter disease duration, and TLOs were mainly associated with ICIs. The frequency of TLOS was inverse to the severity of beta-cell loss, suggesting that TLOs contribute to the progression of islet autoimmunity.

\section{Viral infections}

There is extensive support for a viral contribution to the disease pathogenesis, particularly by enteroviruses (Richardson \& Morgan 2018, Dunne et al. 2019). At the level of the pancreas, enterovirus proteins, enterovirus RNA, and an active anti-viral host response have been demonstrated in the pancreata of T1D donors from each of the three biobanks (Morgan \& Richardson 2014, Geravandi et al. 2021). Viral capsid protein is detected in a small number of beta cells, typically only in ICIs, often in association with hyperexpression of HLA class I molecules and insulitis (Richardson et al. 2009, 2013). There is evidence that enterovirus infections impair beta-cell function (Gallagher et al. 2015), their gene expression, and microRNA regulation (Kim et al. 2016), and may promote or induce the deleterious inflammatory and autoreactive immune responses observed in T1D (Colli et al. 2020).

\section{Abnormalities of the exocrine pancreas}

The exocrine pancreas is also impacted in T1D. Atrophy of acinar cells was originally reported in the mid-1980s (Foulis \& Stewart 1984). By morphometry, T1D pancreata show higher non-exocrine-non-endocrine tissue area to total pancreas area than non-diabetic controls, regardless of age (Bonnet-Serrano et al. 2018). The term 'diabetic exocrine pancreatopathy' (Mohapatra et al. 2016) has been proposed to describe the moderate-tosevere subclinical pancreatic fibrosis and modest exocrine dysfunction that occurs in T1D in the absence of clinical or histopathological evidence of chronic pancreatitis. This pancreatopathy is characterized by (i) decreased pancreatic weight, size, and volume; (ii) increased inter-acinar fibrosis and acinar atrophy with minimal inflammation and no pancreatic ductal changes; (iii) reduced exocrine enzyme output and fecal elastase concentrations; (iv) normal to minimal decrease in coefficient of fat absorption, and (v) lack of progression of exocrine dysfunction over time. Indeed, the T1D pancreas is reduced in weight (CampbellThompson et al. 2016b). Of note, this reduction is observed near disease diagnosis, while pancreata from donors with long disease duration had almost normal pancreatic weights. As the islets constitute only $1-2 \%$ of the pancreas volume, these findings suggest loss of exocrine tissue during the development of T1D. Imaging studies revealed that pancreas volume, volume normalized by body weight, volume normalized by BMI, and volume normalized by body surface area were all lower in patients with recentonset T1D compared to controls (Virostko et al. 2016). Moreover, non-diabetic, autoantibody-positive nPOD donors with insulitis have decreased pancreas weight (Campbell-Thompson et al. 2012). Reduced pancreas volume was recently demonstrated in two imaging studies of living at-risk relatives and newly diagnosed patients; it was more pronounced in newly diagnosed patients than relatives, suggesting a progressive loss of exocrine tissue with disease progression (Campbell-Thompson et al. 2019, Virostko et al. 2019). A loss of volume was observed to further advance in patients that were assessed longitudinally, during the first year after diagnosis (Virostko et al. 2019). Further analysis of nPOD donors revealed that T1D pancreata displayed lower frequency of amylase-negative cell clusters, suggesting a contribution 
of the islet-acinar axis in pancreatic development and a possible abnormality linked to the disease pathogenesis (Kusmartseva et al. 2020). Clinical cohorts of at-risk relatives and patients revealed that trypsinogen and lipase levels were significantly reduced in individuals with multiple autoantibodies, recent-onset, and established T1D compared to control subjects and those with a single autoantibody; amylase levels were lower only in established T1D (Li et al. 2017, Ross et al. 2021). These measurements could serve as circulating biomarkers of pancreas volume, as measured by MRI (Campbell-Thompson et al. 2019). Moreover, lower elastase levels are reported in the stools at T1D diagnosis (Kondrashova et al. 2018). Finally, immune cells infiltrate the exocrine pancreas, including CD8+ and CD4+ T cells, as well CD11c+ cells, which were found in the exocrine pancreas of autoantibody-positive and recentonset T1D donors. There is a predominance of CD8+ T cells and these findings were not linked to pancreatitis (Rodriguez-Calvo et al. 2014); the CD8+ T cells in the exocrine pancreas also include pre-proinsulin reactive cells which then accumulate in the islets (Bender et al. 2020).

\section{Pancreas pathology during preclinical disease stages}

Three different stages have been defined to classify the progression of islet autoimmunity toward clinical T1D (Insel et al. 2015): stage 1, characterized by positivity for at least two autoantibodies; stage 2 , at which glucose intolerance or dysglycemia are demonstrated in those with multiple autoantibodies; and stage 3 , corresponding to the time of diagnosis, when clinical symptoms become apparent. Of note, this classification does not include the stage at which an individual may have single autoantibody positivity, reportedly associated with low risk of future progression, although individuals may progress from single autoantibody positivity to multiple autoantibody positivity and later clinical disease. A critical question in the field is how pancreas pathology evolves and what pathogenetic mechanisms are active during the natural history of the disease. Describing the relationship between pathological change and autoantibodies in relation to disease stages has important therapeutic implications. As noted earlier, the most systematic effort was launched by nPOD across the U.S. and has so far obtained pancreas specimens from 48 organ donors with autoantibodies. However, the identification of autoantibody-positive donors from the general population remains a challenge, and a significant proportion of pancreata from autoantibody-positive donors is transplanted instead of being recovered for research (Burke et al. 2017). The number of donors that can be identified with multiple autoantibodies is limited; most donors with autoantibodies have a single autoantibody.

Single autoantibody positivity likely represents the earlier phase in the natural history of islet autoimmunity. Multiple autoantibody positivity among organ donors may be considered equivalent to the clinical stage 1 or stage 2 , in the rare event that a donor also has an elevated HbA1c; however, one must consider that impaired glucose tolerance and dysglycemia cannot be assessed in organ donors. An earlier study from the Nordic Network for Islet Transplantation identified autoantibody-positive donors (In't Veld et al. 2007) among donors whose pancreas was used for islet isolation. Of the 1507 donors (25-60 years old) screened, 55 had a single autoantibody and 7 had multiple autoantibodies. However, insulitis affecting a minority of islets, was observed only in two donors with multiple autoantibodies, but there was no obvious decrease in ß-cell mass. Another study screened 969 donors and identified 32 with autoantibodies: 9 had multiple autoantibodies but insulitis was not observed (Wiberg et al. 2015). One must consider that for these studies, only small amounts of pancreas tissue were available, and thus lack of insulitis may reflect sampling limitations. However, the examination of larger amounts of tissue in nPOD studies has returned similar observations: nPOD (CampbellThompson et al. 2016a) published the analysis of 21 donors with a single autoantibody, usually in the absence of T1D-associated HLA genes, in whom insulitis was absent. However, two/six donors with multiple autoantibodies and one donor with a single autoantibody had insulitis and T1D-associated HLA types. Another nPOD study observed that CD8+ T cells trended higher in both islet and exocrine areas in some autoantibody-positive donors than controls. Among donors with autoantibodies, and donors with T1D with residual beta cells, there was a polarization of the CD8+ T cells toward the islets (Rodriguez-Calvo et al. 2014). As noted, TLOs were also observed in the pancreas of donors with multiple autoantibodies and insulitis, but not among donors with a single autoantibody (Korpos et al. 2021). This is also consistent with TLOs having a role in promoting islet autoimmunity.

Collectively, these studies demonstrate insulitis and other islet pathological changes in about $40-50 \%$ of donors with multiple autoantibodies. In general, betacell loss was limited (Table 1). Given that most of these donors had normal HbA1c levels, these are more likely to correspond to individuals at stage 1 of the clinical 


\begin{tabular}{l|l|l|r|r|}
$\begin{array}{l}\text { Journal of } \\
\text { Endocrinology }\end{array}$ & $\begin{array}{l}\text { S J Richardson and } \\
\text { A Pugliese }\end{array}$ & $\begin{array}{l}\text { Pancreas pathology in type } 1 \\
\text { diabetes }\end{array}$ & $\mathbf{2 5 2 : 2}$ & $\mathbf{R 5 1}$ \\
\hline
\end{tabular}

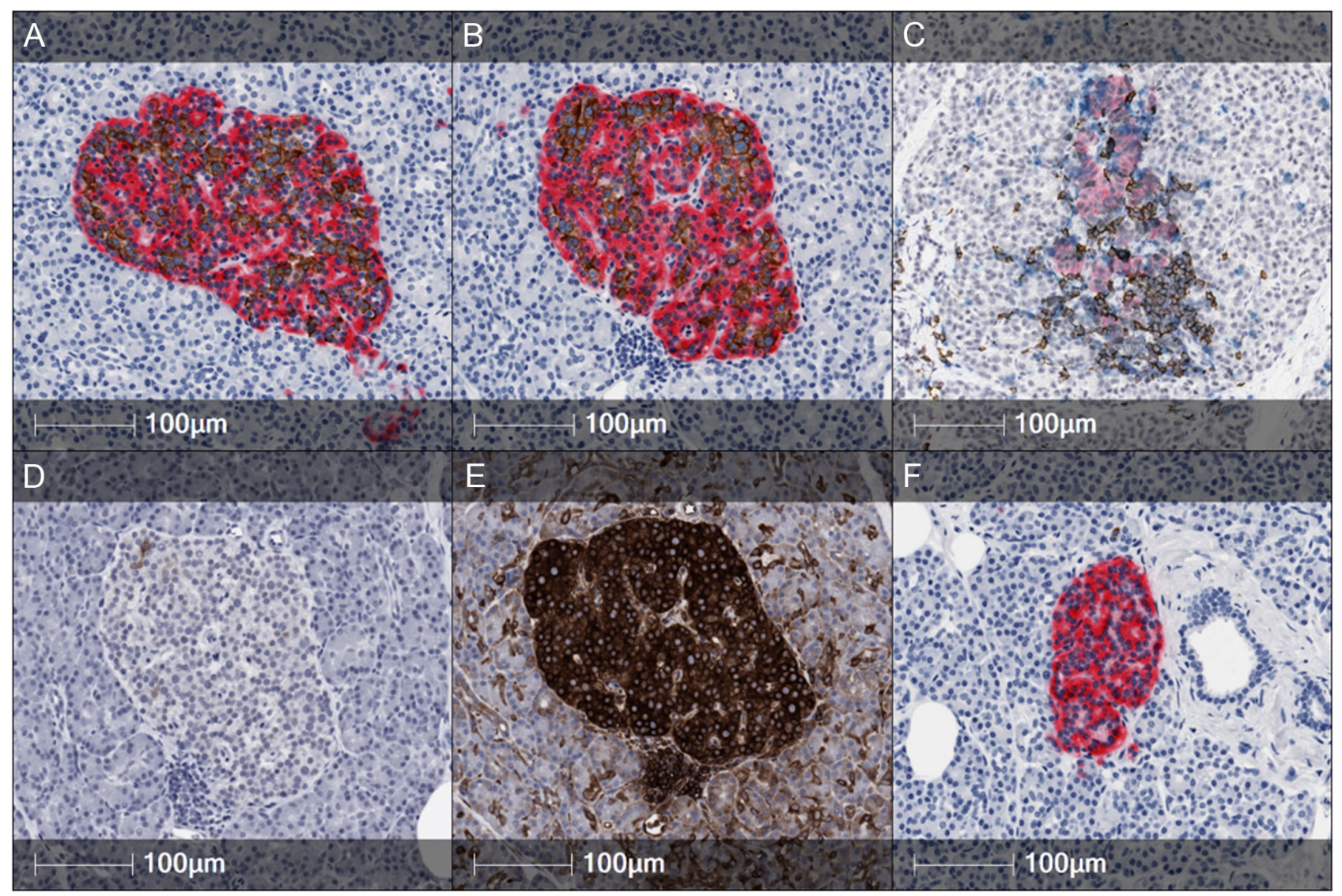

\section{Figure 2}

Representative histologically stained islets from type 1 diabetes pancreas. (A) An insulin-containing islet (ICI) with no evidence of immune cell infiltration (Insulin - brown; glucagon - pink, nPOD donor 6211). (B) An ICI with evidence of a mild insulitic infiltrate at one pole of the islet (Insulin - brown; glucagon - pink, nPOD donor 6211). (C) An ICI with evidence of aggressive insulitis (Insulin - brown; glucagon - black; CD20 brown; CD8 - blue, nPOD 6533). (D) Enteroviral VP1 positive cells within an ICI (serial section in B \& E; VP1 - brown, nPOD 6211). (E) HLA I hyperexpression in an ICI (serial section in B \& C; HLA I - brown, nPOD 6211). (F) An insulin-deficient islet (IDI).

classification. Consistently, the hyperexpression of HLA class I molecules in pancreatic islets reported in the EADB, nPOD, and DiViD cohorts has been also described in donors with multiple autoantibodies (Rodriguez-Calvo et al. 2015); CD8+ T-cell infiltration appeared more prominent in islets with increased HLA class I expression compared to islets with normal expression. This is consistent with the hypothesis that HLA class I expression could attract cytotoxic $\mathrm{T}$ cells to the islets. It has also been shown that autoantibody-positive donors with insulitis may have an increased islet area (Rodriguez-Calvo et al. 2017), possibly a sign of hyperactivity, which was originally proposed by Gepts (Gepts 1965). As the disease progresses and beta-cell dysfunction/loss begins to occur, the demand on beta cells may disrupt their physiology with accumulation of unfolded proteins (Mirmira et al. 2016, Sims et al. 2016), ER stress, and apoptosis (Marhfour et al. 2012, Eizirik et al. 2013), which have all be shown to precede clinical onset. As noted, the accumulation of unprocessed proinsulin (Eizirik et al. 2013) which is released to the circulation is a key sign of ER stress and beta-cell dysfunction (Røder et al. 1994, Sims et al. 2016); this finds correspondence in pancreas pathology in the increased proinsulin:insulin ratio in the pancreas of double autoantibody-positive nPOD donors and, importantly, in some donors with a single autoantibody (Rodriguez-Calvo et al. 2017). Thus, although not all the known expressions of the disease pathogenesis have been found in the pancreas of donors with a single autoantibody, there is evidence for abnormalities at this stage as well. Table 1 illustrates the presence of key pathology features across the natural history of T1D, with examples of these shown in Fig. 2.

\section{Conclusions}

In the last two decades, the implementation of dedicated efforts for the collection and analysis of pancreas tissue from patients with T1D diabetes, largely post-mortem, has https://joe.bioscientifica.com https://doi.org/10.1530/JOE-21-0358 (c) 2021 Society for Endocrinology Published by Bioscientifica Ltd. 
supported afforded much progress in the characterization of pancreas pathology. The classical features, insulitis and beta-cell loss, are now better understood and characterized in relation to age and disease duration. There is mounting evidence that beta-cell dysfunction is a critical factor in the disease pathogenesis, and increased recognition that the true extent of beta-cell loss may be overestimated as there is evidence that beta cells may persist in many patients for years after diagnosis. Moreover, the autoantibody screening programs launched to identify donors with preclinical T1D provide information about the evolution of the disease process in the pancreas, and it is possible to drive parallels to the clinical stages of disease. It appears that beta-cell loss and insulitis may be absent/limited in the early stages of T1D (single AAb, stage 1 T1D), and become more prominent at later stages. This is consistent with more severe decline of insulin secretion during the 6 months preceding and the 6 months following diagnosis (Bogun et al. 2020). Beta-cell destruction is not complete by the time of diagnosis in many patients, but it continues over time, roughly for about 10 years after onset. Another consideration is that insulitis, islet autoimmunity and inflammation appear chronic, but more prevalent and perhaps severe (particularly in young individuals) closer or even after diagnosis, but can persist for years after diagnosis together with other signs of inflammation. Together with increased recognition of pathology and clinical disease endotypes, all of the above findings have implications for advancing therapeutic strategies and clinical trials. One-hundred years after the discovery of insulin, our understanding of the pathology of T1D is still evolving; however, much progress has been made, despite limited access to the target organ, and much more progress is expected in the future, at a faster pace, based on the implementation of well-organized recovery efforts, advancing technologies, and scientific collaboration.

\section{Declaration of interest}

The authors declare that there is no conflict of interest that could be perceived as prejudicing the impartiality of this review.

\section{Funding}

We acknowledge financial support from the European Union's Seventh Framework Programme PEVNET [FP7/2007-2013] under grant agreement number 261441. The participants of the PEVNET consortium are described at http://www.uta.fi/med/pevnet/publications.html. Additional support was from a Diabetes Research Wellness Foundation NonClinical Research Fellowship, a JDRF Career Development Award (5-CDA2014-221-A-N) and an MRC Project Grant MR/P010695/1 to S J R, a JDRF research grant awarded to the nPOD-V consortium (JDRF 25-2012-516). Research reviewed here involves patients from the EADB, DiViD and nPOD collections; nPOD, The Network for Pancreatic Organ Donors with Diabetes, a collaborative type 1 diabetes research project. $\mathrm{PPOD}$ and AP are supported by grants from JDRF (5-SRA-2018-557-Q-R) and The Leona M. and Barry B. Helmsley Charitable Trust (The George Eisenbarth nPOD Award for Team Science; 2015PG-T1D052, 2018PG-T1D060, and 211204895). Organ Procurement Organizations (OPO) partnering with nPOD to provide research resources are listed at www.jdrfnpod.org/our-partners. php. AP is supported also by the Diabetes Research Institute Foundation, Hollywood, Florida, USA.

\section{Author contribution statement}

Both authors contributed to researching and writing this article.

\section{Acknowledgements}

The authors would like to thank the nPOD Pathology Core for providing access to scanned, stained nPOD sections.

\section{References}

Apaolaza PS, Balcacean D, Zapardiel-Gonzalo J, Nelson G, Lenchik N, Akhbari P, Gerling I, Richardson SJ, Rodriguez-Calvo T \& nPOD-Virus Group 2021 Islet expression of type I interferon response sensors is associated with immune infiltration and viral infection in type 1 diabetes. Science Advances 7 eabd6527. (https://doi.org/10.1126/sciadv. abd6527)

Arif S, Leete P, Nguyen V, Marks K, Nor NM, Estorninho M, KronenbergVersteeg D, Bingley PJ, Todd JA, Guy C, et al. 2014 Blood and islet phenotypes indicate immunological heterogeneity in type 1 diabetes. Diabetes 63 3835-3845. (https://doi.org/10.2337/db14-0365)

Atkinson MA 2014 Pancreatic biopsies in type 1 diabetes: revisiting the myth of Pandora's box. Diabetologia 57 656-659. (https://doi. org/10.1007/s00125-013-3159-7)

Battaglia M, Ahmed S, Anderson MS, Atkinson MA, Becker D, Bingley PJ, Bosi E, Brusko TM, Dimeglio LA, Evans-Molina C, et al. 2020 Introducing the endotype concept to address the challenge of disease heterogeneity in type 1 diabetes. Diabetes Care 43 5-12. (https://doi.org/10.2337/dc19-0880)

Beery ML, Jacobsen LM, Atkinson MA, Butler AE \& Campbell-Thompson M 2019 Islet amyloidosis in a child with type 1 diabetes. Islets 11 44-49. (https://doi.org/10.1080/19382014.2019.1599707)

Bender C, Rodriguez-Calvo T, Amirian N, Coppieters KT \& Von Herrath MG 2020 The healthy exocrine pancreas contains preproinsulin-specific CD8 T cells that attack islets in type 1 diabetes. Science Advances 6 eabc5586. (https://doi.org/10.1126/sciadv.abc5586)

Benkahla MA, Sabouri S, Kiosses WB, Rajendran S, Quesada-Masachs E \& Von Herrath MG 2021 HLA class I hyper-expression unmasks beta cells but not alpha cells to the immune system in pre-diabetes. Journal of Autoimmunity 119 102628. (https://doi.org/10.1016/j.jaut.2021.102628)

Bogdani M 2016 Thinking outside the cell: a key role for hyaluronan in the pathogenesis of human type 1 diabetes. Diabetes 65 2105-2114. (https://doi.org/10.2337/db15-1750)

Bogdani M, Johnson PY, Potter-Perigo S, Nagy N, Day AJ, Bollyky PL \& Wight TN 2014a Hyaluronan and hyaluronan binding proteins accumulate in both human type 1 diabetic islets and lymphoid tissues and associate with inflammatory cells in insulitis. Diabetes 63 2727-2743. (https://doi.org/10.2337/db13-1658)

Bogdani M, Korpos E, Simeonovic CJ, Parish CR, Sorokin L \& Wight TN $2014 b$ Extracellular matrix components in the pathogenesis of type https://joe.bioscientifica.com

https://doi.org/10.1530/JOE-21-0358 (c) 2021 Society for Endocrinology Published by Bioscientifica Ltd. Printed in Great Britain 
1 diabetes. Current Diabetes Reports 14 552. (https://doi.org/10.1007/ s11892-014-0552-7)

Bogdani M, Speake C, Dufort MJ, Johnson PY, Larmore MJ, Day AJ, Wight TN, Lernmark Å \& Greenbaum CJ 2020 Hyaluronan deposition in islets may precede and direct the location of islet immune-cell infiltrates. Diabetologia 63 549-560. (https://doi.org/10.1007/s00125019-05066-7)

Bogun MM, Bundy BN, Goland RS \& Greenbaum CJ 2020 C-peptide levels in subjects followed longitudinally before and after type 1 diabetes diagnosis in TrialNet. Diabetes Care 43 1836-1842. (https://doi. org/10.2337/dc19-2288)

Bonnet-Serrano F, Diedisheim M, Mallone R \& Larger E 2018 Decreased $\alpha$-cell mass and early structural alterations of the exocrine pancreas in patients with type 1 diabetes: an analysis based on the nPOD repository. PLoS ONE 13 e0191528. (https://doi.org/10.1371/journal.pone.0191528)

Bottazzo GF 1986 Lawrence lecture. Death of a beta cell: homicide or suicide? Diabetic Medicine 3 119-130. (https://doi. org/10.1111/j.1464-5491.1986.tb00722.x)

Bottazzo GF, Dean BM, Mcnally JM, Mackay EH, Swift PG \& Gamble DR 1985 In situ characterization of autoimmune phenomena and expression of HLA molecules in the pancreas in diabetic insulitis. New England Journal of Medicine 313 353-360. (https://doi.org/10.1056/ NEJM198508083130604)

Brozzi F \& Eizirik DL 2016 ER stress and the decline and fall of pancreatic beta cells in type 1 diabetes. Upsala Journal of Medical Sciences $\mathbf{1 2 1}$ 133-139. (https://doi.org/10.3109/03009734.2015.1135217)

Burch TC, Morris MA, Campbell-Thompson M, Pugliese A, Nadler JL \& Nyalwidhe JO 2015 Proteomic analysis of disease stratified human pancreas tissue indicates unique signature of type 1 diabetes. PLOS ONE 10 e0135663. (https://doi.org/10.1371/journal.pone.0135663)

Burke 3rd GW, Posgai AL, Wasserfall CH, Atkinson MA \& Pugliese A 2017 Raising awareness: the need to promote allocation of pancreata from rare nondiabetic donors with pancreatic islet autoimmunity to type 1 diabetes research. American Journal of Transplantation 17 306-307. (https://doi.org/10.1111/ajt.13983)

Campbell IL, Oxbrow L, West J \& Harrison LC 1988 Regulation of MHC protein expression in pancreatic beta-cells by interferon-gamma and tumor necrosis factor-alpha. Molecular Endocrinology 2 101-107. (https://doi.org/10.1210/mend-2-2-101)

Campbell-Thompson M, Wasserfall C, Montgomery EL, Atkinson MA \& Kaddis JS 2012 Pancreas organ weight in individuals with diseaseassociated autoantibodies at risk for type 1 diabetes. JAMA $\mathbf{3 0 8}$ 2337-2339. (https://doi.org/10.1001/jama.2012.15008)

Campbell-Thompson ML, Atkinson MA, Butler AE, Chapman NM, Frisk G, Gianani R, Giepmans BN, Von Herrath MG, Hyoty H, Kay TW, et al. 2013 The diagnosis of insulitis in human type 1 diabetes. Diabetologia 56 2541-2543. (https://doi.org/10.1007/s00125-013-3043-5)

Campbell-Thompson M, Rodriguez-Calvo T \& Battaglia M 2015 Abnormalities of the exocrine pancreas in type 1 diabetes. Current Diabetes Reports 15 79. (https://doi.org/10.1007/s11892-015-0653-y)

Campbell-Thompson M, Fu A, Kaddis JS, Wasserfall C, Schatz DA, Pugliese A \& Atkinson MA 2016a Insulitis and beta-cell mass in the natural history of type 1 diabetes. Diabetes 65 719-731. (https://doi org/10.2337/db15-0779)

Campbell-Thompson ML, Kaddis JS, Wasserfall C, Haller MJ, Pugliese A, Schatz DA, Shuster JJ \& Atkinson MA 2016b The influence of type 1 diabetes on pancreatic weight. Diabetologia 59 217-221. (https://doi. org/10.1007/s00125-015-3752-z)

Campbell-Thompson ML, Atkinson MA, Butler AE, Giepmans BN, Von Herrath MG, Hyoty H, Kay TW, Morgan NG, Powers AC, Pugliese A, et al. 2017 Re-addressing the 2013 consensus guidelines for the diagnosis of insulitis in human type 1 diabetes: is change necessary? Diabetologia 60 753-755. (https://doi.org/10.1007/s00125-016-4195-x)

Campbell-Thompson ML, Filipp SL, Grajo JR, Nambam B, Beegle R, Middlebrooks EH, Gurka MJ, Atkinson MA, Schatz DA \& Haller M] 2019 Relative pancreas volume is reduced in first-degree relatives of patients with type 1 diabetes. Diabetes Care 42 281-287. (https://doi. org/10.2337/dc18-1512)

Colli ML, Hill JLE, Marroquí L, Chaffey J, Dos Santos RS, Leete P, Coomans de Brachène A, Paula FMM, Op de Beeck A, Castela A, et al. 2018 PDL1 is expressed in the islets of people with type 1 diabetes and is up-regulated by interferons- $\alpha$ and- $\gamma$ via IRF1 induction. EBioMedicine 36 367-375.(https://doi.org/10.1016/j.ebiom.2018.09.040)

Colli ML, Ramos-Rodríguez M, Nakayasu ES, Alvelos MI, Lopes M, Hill JLE, Turatsinze JV, Coomans De Brachène A, Russell MA, Raurell-Vila H, et al. 2020 An integrated multi-omics approach identifies the landscape of interferon- $\alpha$-mediated responses of human pancreatic beta cells. Nature Communications 11 2584. (https://doi.org/10.1038/s41467-02016327-0)

Coppieters KT, Dotta F, Amirian N, Campbell PD, Kay TW, Atkinson MA, Roep BO \& Von Herrath MG 2012 Demonstration of islet-autoreactive CD8 T cells in insulitic lesions from recent onset and long-term type 1 diabetes patients. Journal of Experimental Medicine 209 51-60. (https:// doi.org/10.1084/jem.20111187)

de Beeck AO \& Eizirik DL 2016 Viral infections in type 1 diabetes mellitus why the beta cells? Nature Reviews: Endocrinology 12 263-273. (https:// doi.org/10.1038/nrendo.2016.30)

Denroche HC \& Verchere CB 2018 IAPP and type 1 diabetes: implications for immunity, metabolism and islet transplants. Journal of Molecular Endocrinology 60 R57-R75. (https://doi.org/10.1530/JME-17-0138)

Dotta F, Censini S, Van Halteren AG, Marselli L, Masini M, Dionisi S, Mosca F, Boggi U, Muda AO, Prato SD, et al. 2007 Coxsackie B4 virus infection of beta cells and natural killer cell insulitis in recent-onset type 1 diabetic patients. PNAS 104 5115-5120. (https://doi.org/10.1073/ pnas.0700442104)

Dunne JL, Richardson SJ, Atkinson MA, Craig ME, Dahl-Jorgensen K, Flodstrom-Tullberg M, Hyoty H, Insel RA, Lernmark Å, Lloyd RE, et al. 2019 Rationale for enteroviral vaccination and antiviral therapies in human type 1 diabetes. Diabetologia 62 744-753. (https://doi. org/10.1007/s00125-019-4811-7)

Eizirik DL \& Colli ML 2020 Revisiting the role of inflammation in the loss of pancreatic $\beta$-cells in T1DM. Nature Reviews: Endocrinology 16 611-612. (https://doi.org/10.1038/s41574-020-00409-6)

Eizirik DL \& Coomans de Brachène A 2017 Checks and balances-the limits of $\beta$-cell endurance to ER stress. Diabetes 66 1467-1469. (https://doi. org/10.2337/dbi17-0018)

Eizirik DL, Miani M \& Cardozo AK 2013 Signalling danger: endoplasmic reticulum stress and the unfolded protein response in pancreatic islet inflammation. Diabetologia 56 234-241. (https://doi.org/10.1007/ s00125-012-2762-3)

Evans-Molina C, Sims EK, Dimeglio LA, Ismail HM, Steck AK, Palmer JP, Krischer JP, Geyer S, Xu P, Sosenko JM, et al. 2018 $\beta$ Cell dysfunction exists more than 5 years before type 1 diabetes diagnosis. JCI Insight 3 e120877. (https://doi.org/10.1172/jci.insight.120877)

Flatt AJS, Greenbaum CJ, Shaw JAM \& Rickels MR 2021 Pancreatic islet reserve in type 1 diabetes. Annals of the New York Academy of Sciences 1495 40-54. (https://doi.org/10.1111/nyas.14572)

Foulis AK \& Stewart JA 1984 The pancreas in recent-onset type 1 (insulindependent) diabetes mellitus: insulin content of islets, insulitis and associated changes in the exocrine acinar tissue. Diabetologia $\mathbf{2 6}$ 456-461. (https://doi.org/10.1007/BF00262221)

Foulis AK, Liddle CN, Farquharson MA, Richmond JA \& Weir RS 1986 The histopathology of the pancreas in type 1 (insulin-dependent) diabetes mellitus: a 25 -year review of deaths in patients under 20 years of age in the United Kingdom. Diabetologia 29 267-274. (https://doi.org/10.1007/ BF00452061)

Foulis AK, Farquharson MA \& Hardman R 1987 Aberrant expression of class II major histocompatibility complex molecules by B cells and hyperexpression of class I major histocompatibility complex molecules by insulin containing islets in type 1 (insulin-dependent) diabetes mellitus. Diabetologia 30 333-343. (https://doi.org/10.1007/ BF00299027) https://joe.bioscientifica.com

https://doi.org/10.1530/JOE-21-0358 (c) 2021 Society for Endocrinology Published by Bioscientifica Ltd. Printed in Great Britain 
Fu Z, Gilbert ER \& Liu D 2013 Regulation of insulin synthesis and secretion and pancreatic beta-cell dysfunction in diabetes. Current Diabetes Reviews 9 25-53. (https://doi.org/10.2174/157339913804143225)

Gallagher GR, Brehm MA, Finberg RW, Barton BA, Shultz LD, Greiner DL, Bortell R \& Wang JP 2015 Viral infection of engrafted human islets leads to diabetes. Diabetes 64 1358-1369. (https://doi.org/10.2337/db141020)

Gepts W 1965 Pathologic anatomy of the pancreas in juvenile diabetes mellitus. Diabetes 14 619-633. (https://doi.org/10.2337/diab.14.10.619)

Gepts W \& De Mey J 1978 Islet cell survival determined by morphology. An immunocytochemical study of the islets of Langerhans in juvenile diabetes mellitus. Diabetes 27 (Supplement 1) 251-261. (https://doi. org/10.2337/diab.27.1.s251)

Geravandi S, Richardson S, Pugliese A \& Maedler K 2021 Localization of enteroviral RNA within the pancreas in donors with T1D and T1Dassociated autoantibodies. Cell Reports: Medicine 2 100371. (https://doi. org/10.1016/j.xcrm.2021.100371)

Gianani R, Campbell-Thompson M, Sarkar SA, Wasserfall C, Pugliese A, Solis JM, Kent SC, Hering BJ, West E, Steck A, et al. 2010 Dimorphic histopathology of long-standing childhood-onset diabetes. Diabetologia 53 690-698. (https://doi.org/10.1007/s00125-009-1642-y)

Greenbaum CJ, Anderson AM, Dolan LM, Mayer-Davis EJ, Dabelea D, Imperatore G, Marcovina S, Pihoker C \& SEARCH Study Group 2009 Preservation of beta-cell function in autoantibody-positive youth with diabetes. Diabetes Care 32 1839-1844. (https://doi.org/10.2337/dc082326)

Greenbaum CJ, Beam CA, Boulware D, Gitelman SE, Gottlieb PA, Herold KC, Lachin JM, Mcgee P, Palmer JP, Pescovitz MD, et al. 2012 Fall in C-peptide during first 2 years from diagnosis: evidence of at least two distinct phases from composite type 1 diabetes TrialNet data. Diabetes 61 2066-2073. (https://doi.org/10.2337/db11-1538)

Grzesik WJ, Nadler JL, Machida Y, Nadler JL, Imai Y \& Morris MA 2015 Expression pattern of 12-lipoxygenase in human islets with type 1 diabetes and type 2 diabetes. Journal of Clinical Endocrinology and Metabolism 100 E387-E395. (https://doi.org/10.1210/jc.2014-3630)

Hanafusa T, Miyazaki A, Miyagawa J, Tamura S, Inada M, Yamada K, Shinji Y, Katsura H, Yamagata K \& Itoh N 1990 Examination of islets in the pancreas biopsy specimens from newly diagnosed type 1 (insulindependent) diabetic patients. Diabetologia 33 105-111. (https://doi. org/10.1007/BF00401048)

Hao W, Gitelman S, Dimeglio LA, Boulware D, Greenbaum CJ \& Type 1 Diabetes TrialNet Study Group 2016 Fall in C-peptide during first 4 years from diagnosis of type 1 diabetes: variable relation to age, $\mathrm{HbA1c}$, and insulin dose. Diabetes Care 39 1664-1670. (https://doi.org/10.2337/ dc16-0360)

Heaton DA, Millward BA, Gray IP, Tun Y, Hales CN, Pyke DA \& Leslie RD 1988 Increased proinsulin levels as an early indicator of B-cell dysfunction in non-diabetic twins of type 1 (insulin-dependent) diabetic patients. Diabetologia 31 182-184. (https://doi.org/10.1007/ BF00276853)

Hyoty H 2016 Viruses in type 1 diabetes. Pediatric Diabetes 17 (Supplement 22) 56-64. (https://doi.org/10.1111/pedi.12370)

Imagawa A, Hanafusa T, Tamura S, Moriwaki M, Itoh N, Yamamoto K, Iwahashi H, Yamagata K, Waguri M, Nanmo T, et al. 2001 Pancreatic biopsy as a procedure for detecting in situ autoimmune phenomena in type 1 diabetes: close correlation between serological markers and histological evidence of cellular autoimmunity. Diabetes 50 1269-1273. (https://doi.org/10.2337/diabetes.50.6.1269)

Imai Y, Dobrian AD, Morris MA, Taylor-Fishwick DA \& Nadler JL 2016 Lipids and immunoinflammatory pathways of beta cell destruction. Diabetologia 59 673-678. (https://doi.org/10.1007/s00125-016-3890-y)

Insel RA, Dunne JL, Atkinson MA, Chiang JL, Dabelea D, Gottlieb PA, Greenbaum CJ, Herold KC, Krischer JP, Lernmark ^̊, et al. 2015 Staging presymptomatic type 1 diabetes: a scientific statement of JDRF, the Endocrine Society, and the American Diabetes Association. Diabetes Care 38 1964-1974. (https://doi.org/10.2337/dc15-1419)
In't Veld P 2011 Insulitis in human type 1 diabetes: the quest for an elusive lesion. Islets 3 131-138. (https://doi.org/10.4161/isl.3.4.15728)

In't Veld P, Lievens D, De Grijse J, Ling Z, Van Der Auwera B, PipeleersMarichal M, Gorus F \& Pipeleers D 2007 Screening for insulitis in adult autoantibody-positive organ donors. Diabetes 56 2400-2404. (https:// doi.org/10.2337/db07-0416)

Itoh N, Hanafusa T, Miyazaki A, Miyagawa J, Yamagata K, Yamamoto K, Waguri M, Imagawa A, Tamura S \& Inada M 1993 Mononuclear cell infiltration and its relation to the expression of major histocompatibility complex antigens and adhesion molecules in pancreas biopsy specimens from newly diagnosed insulin-dependent diabetes mellitus patients. Journal of Clinical Investigation 92 2313-2322. (https://doi.org/10.1172/JCI116835)

Jeyam A, Colhoun H, McGurnaghan S, Blackbourn L, McDonald TJ, Palmer CNA, McKnight JA, Strachan MWJ, Patrick AW, Chalmers J, et al. 2021 Clinical impact of residual C-peptide secretion in type 1 diabetes on glycemia and microvascular complications. Diabetes Care 44 390-398.(https://doi.org/10.2337/dc20-0567)

Keenan HA, Sun JK, Levine J, Doria A, Aiello LP, Eisenbarth G, BonnerWeir S \& King GL 2010 Residual insulin production and pancreatic ss-cell turnover after 50 years of diabetes: Joslin Medalist Study. Diabetes 59 2846-2853. (https://doi.org/10.2337/db10-0676)

Kim KW, Ho A, Alshabee-Akil A, Hardikar AA, Kay TW, Rawlinson WD \& Craig ME 2016 Coxsackievirus B5 infection induces dysregulation of microRNAs predicted to target known type 1 diabetes risk genes in human pancreatic islets. Diabetes 65 996-1003. (https://doi. org/10.2337/db15-0956)

Klinke DJ 2008 Extent of beta cell destruction is important but insufficient to predict the onset of type 1 diabetes mellitus. PLOS ONE 3 e1374. (https://doi.org/10.1371/journal.pone.0001374)

Klinke DJ 2011 Age-corrected beta cell mass following onset of type 1 diabetes mellitus correlates with plasma C-peptide in humans. PLoS ONE 6 e26873. (https://doi.org/10.1371/journal.pone.0026873)

Kondrashova A, Nurminen N, Lehtonen J, Hyöty M, Toppari J, Ilonen J, Veijola R, Knip M \& Hyöty H 2018 Exocrine pancreas function decreases during the progression of the beta-cell damaging process in young prediabetic children. Pediatric Diabetes 19 398-402. (https://doi. org/10.1111/pedi.12592)

Korpos É, Kadri N, Kappelhoff R, Wegner J, Overall CM, Weber E, Holmberg D, Cardell S \& Sorokin L 2013 The peri-islet basement membrane, a barrier to infiltrating leukocytes in type 1 diabetes in mouse and human. Diabetes 62 531-542. (https://doi.org/10.2337/ db12-0432)

Korpos É, Kadri N, Loismann S, Findeisen CR, Arfuso F, Burke 3rd GW, Richardson SJ, Morgan NG, Bogdani M, Pugliese A, et al. 2021 Identification and characterisation of tertiary lymphoid organs in human type 1 diabetes. Diabetologia 64 1626-1641. (https://doi. org/10.1007/s00125-021-05453-z)

Krischer JP, Liu X, Lernmark Å, Hagopian WA, Rewers MJ, She JX, Toppari J, Ziegler AG, Akolkar B \& TEDDY Study Group 2021 Characteristics of children diagnosed with type 1 diabetes before vs after 6 years of age in the TEDDY cohort study. Diabetologia 64 2247-2257. (https://doi. org/10.1007/s00125-021-05514-3)

Krogvold L, Edwin B, Buanes T, Ludvigsson J, Korsgren O, Hyoty H, Frisk G, Hanssen KF \& Dahl-Jorgensen K 2014 Pancreatic biopsy by minimal tail resection in live adult patients at the onset of type 1 diabetes: experiences from the DiViD study. Diabetologia 57 841-843. (https:// doi.org/10.1007/s00125-013-3155-y)

Krogvold L, Edwin B, Buanes T, Frisk G, Skog O, Anagandula M, Korsgren O, Undlien D, Eike MC, Richardson SJ, et al. 2015a Detection of a lowgrade enteroviral infection in the islets of langerhans of living patients newly diagnosed with type 1 diabetes. Diabetes 64 1682-1687.(https:// doi.org/10.2337/db14-1370)

Krogvold L, Skog O, Sundstrom G, Edwin B, Buanes T, Hanssen KF, Ludvigsson J, Grabherr M, Korsgren O \& Dahl-Jorgensen K 2015b Function of isolated pancreatic islets from patients at onset of type https://joe.bioscientifica.com https://doi.org/10.1530/JOE-21-0358 (c) 2021 Society for Endocrinology Published by Bioscientifica Ltd. Printed in Great Britain 
1 diabetes: insulin secretion can be restored after some days in a nondiabetogenic environment in vitro: results from the DiViD study. Diabetes 64 2506-2512. (https://doi.org/10.2337/db14-1911)

Krogvold L, Wiberg A, Edwin B, Buanes T, Jahnsen FL, Hanssen KF, Larsson E, Korsgren O, Skog O \& Dahl-Jorgensen K 2016 Insulitis and characterisation of infiltrating $\mathrm{T}$ cells in surgical pancreatic tail resections from patients at onset of type 1 diabetes. Diabetologia $\mathbf{5 9}$ 492-501. (https://doi.org/10.1007/s00125-015-3820-4)

Kuipers HF, Rieck M, Gurevich I, Nagy N, Butte MJ, Negrin RS, Wight TN, Steinman L \& Bollyky PL 2016 Hyaluronan synthesis is necessary for autoreactive T-cell trafficking, activation, and Th1 polarization. PNAS 113 1339-1344. (https://doi.org/10.1073/pnas.1525086113)

Kundu R, Knight R, Dunga M \& Peakman M 2018 In silico and ex vivo approaches indicate immune pressure on capsid and non-capsid regions of coxsackie B viruses in the human system. PLOS ONE 13 e0199323. (https://doi.org/10.1371/journal.pone.0199323)

Kusmartseva I, Beery M, Hiller H, Padilla M, Selman S, Posgai A, Nick HS, Campbell-Thompson M, Schatz DA, Haller MJ, et al. 2020 Temporal analysis of amylase expression in control, autoantibody-positive, and type 1 diabetes pancreatic tissues. Diabetes 69 60-66. (https://doi. org/10.2337/db19-0554)

Lecompte PM 1958 Insulitis in early juvenile diabetes. AMA Archives of Pathology 66 450-457.

Leete P, Willcox A, Krogvold L, Dahl-Jorgensen K, Foulis AK, Richardson SJ \& Morgan NG 2016 Differential insulitic profiles determine the extent of beta cell destruction and the age at onset of type 1 diabetes. Diabetes 65 1362-1369. (https://doi.org/10.2337/db15-1615)

Leete P, Oram RA, McDonald TJ, Shields BM, Ziller C, TIGI Study Team, Hattersley AT, Richardson SJ \& Morgan NG 2020 Studies of insulin and proinsulin in pancreas and serum support the existence of aetiopathological endotypes of type 1 diabetes associated with age at diagnosis. Diabetologia 63 1258-1267. (https://doi.org/10.1007/s00125020-05115-6)

Lernmark A, Kloppel G, Stenger D, Vathanaprida C, Falt K, LandinOlsson M, Baskin DG, Palmer JP, Gown AM \& Petersen JS 1995 Heterogeneity of islet pathology in two infants with recent onset diabetes mellitus. Virchows Archiv 425 631-640. (https://doi. org/10.1007/BF00199353)

Li X, Campbell-Thompson M, Wasserfall CH, Mcgrail K, Posgai A, Schultz AR, Brusko TM, Shuster J, Liang F, Muir A, et al. 2017 Serum trypsinogen levels in type 1 diabetes. Diabetes Care 40 577-582. (https://doi.org/10.2337/dc16-1774)

Ludvigsson J \& Heding L 1982 Abnormal proinsulin/C-peptide ratio in juvenile diabetes. Acta Diabetologica Latina 19 351-358. (https://doi. org/10.1007/BF02629258)

Lundberg M, Seiron P, Ingvast S, Korsgren O \& Skog O 2017 a Insulitis in human diabetes: a histological evaluation of donor pancreases. Diabetologia 60 346-353. (https://doi.org/10.1007/s00125-016-4140-z)

Lundberg M, Seiron P, Ingvast S, Korsgren O \& Skog O 2017b Re-addressing the 2013 consensus guidelines for the diagnosis of insulitis in human type 1 diabetes: is change necessary? Reply to Campbell-Thompson ML, Atkinson MA, Butler AE, et al. (letter). Diabetologia 60 756-757. (https://doi.org/10.1007/s00125-017-4212-8)

Maahs DM, West NA, Lawrence JM \& Mayer-Davis EJ 2010 Epidemiology of type 1 diabetes. Endocrinology and Metabolism Clinics of North America 39 481-497. (https://doi.org/10.1016/j.ecl.2010.05.011)

Marhfour I, Lopez XM, Lefkaditis D, Salmon I, Allagnat F, Richardson SJ, Morgan NG \& Eizirik DL 2012 Expression of endoplasmic reticulum stress markers in the islets of patients with type 1 diabetes. Diabetologia 55 2417-2420. (https://doi.org/10.1007/s00125-012-2604-3)

Marre ML, James EA \& Piganelli JD 2015 Beta cell ER stress and the implications for immunogenicity in type 1 diabetes. Frontiers in Cell and Developmental Biology 3 67. (https://doi.org/10.3389/fcell.2015.00067)

Marroqui L, Lopes M, Dos Santos RS, Grieco FA, Roivainen M, Richardson SJ, Morgan NG, Op De Beeck A \& Eizirik DL 2015 Differential cell autonomous responses determine the outcome of
Coxsackievirus infections in murine pancreatic alpha and beta cells. eLife 4 e06990. (https://doi.org/10.7554/eLife.06990)

Marroqui L, Dos Santos RS, Op De Beeck A, Coomans De Brachène A, Marselli L, Marchetti P \& Eizirik DL 2017 Interferon- $\alpha$ mediates human beta cell HLA class I overexpression, endoplasmic reticulum stress and apoptosis, three hallmarks of early human type 1 diabetes. Diabetologia 60 656-667. (https://doi.org/10.1007/s00125-016-4201-3)

Meier JJ, Bhushan A, Butler AE, Rizza RA \& Butler PC 2005a Sustained beta cell apoptosis in patients with long-standing type 1 diabetes: indirect evidence for islet regeneration? Diabetologia 48 2221-2228. (https:// doi.org/10.1007/s00125-005-1949-2)

Meier JJ, Ritzel RA, Maedler K, Gurlo T \& Butler PC 2005b Increased vulnerability of newly forming beta cells to cytokine-induced cell death. Diabetologia 49 83-89. (https://doi.org/10.1007/s00125-005-0069-3)

Mirmira RG, Sims EK, Syed F \& Evans-Molina C 2016 Biomarkers of betacell stress and death in type 1 diabetes. Current Diabetes Reports 1695. (https://doi.org/10.1007/s11892-016-0783-x)

Mohapatra S, Majumder S, Smyrk TC, Zhang L, Matveyenko A, Kudva YC $\&$ Chari ST 2016 Diabetes mellitus is associated with an exocrine pancreatopathy: conclusions from a review of literature. Pancreas $\mathbf{4 5}$ 1104-1110. (https://doi.org/10.1097/MPA.0000000000000609)

Morgan NG 2017 Bringing the human pancreas into focus: new paradigms for the understanding of type 1 diabetes. Diabetic Medicine 34 879-886. (https://doi.org/10.1111/dme.13365)

Morgan NG \& Richardson SJ 2014 Enteroviruses as causative agents in type 1 diabetes: loose ends or lost cause? Trends in Endocrinology and Metabolism 25 611-619. (https://doi.org/10.1016/j.tem.2014.08.002)

Morgan NG, Leete P, Foulis AK \& Richardson SJ 2014 Islet inflammation in human type 1 diabetes mellitus. IUBMB Life 66 723-734. (https://doi. org/10.1002/iub.1330)

Nagy N, Kaber G, Johnson PY, Gebe JA, Preisinger A, Falk BA, Sunkari VG, Gooden MD, Vernon RB, Bogdani M, et al. 2015 Inhibition of hyaluronan synthesis restores immune tolerance during autoimmune insulitis. Journal of Clinical Investigation 125 3928-3940. (https://doi. org/10.1172/JCI79271)

Nekoua MP, Bertin A, Sane F, Gimeno JP, Fournier I, Salzet M, Engelmann I, Alidjinou EK \& Hober D 2021 Persistence of Coxsackievirus B4 in pancreatic $\beta$ cells disturbs insulin maturation, pattern of cellular proteinS, and DNA methylation. Microorganisms 9 1125. (https://doi. org/10.3390/microorganisms9061125)

Oram RA, Jones AG, Besser RE, Knight BA, Shields BM, Brown RJ, Hattersley AT \& Mcdonald TJ 2014 The majority of patients with long-duration type 1 diabetes are insulin microsecretors and have functioning beta cells. Diabetologia 57 187-191. (https://doi. org/10.1007/s00125-013-3067-x)

Oram RA, Mcdonald TJ, Shields BM, Hudson MM, Shepherd MH, Hammersley S, Pearson ER, Hattersley AT \& UNITED Team 2015 Most people with long-duration type 1 diabetes in a large population-based study are insulin microsecretors. Diabetes Care 38 323-328. (https:// doi.org/10.2337/dc14-0871)

Osum KC, Burrack AL, Martinov T, Sahli NL, Mitchell JS, Tucker CG, Pauken KE, Papas K, Appakalai B, Spanier JA, et al. 2018 Interferongamma drives programmed death-ligand 1 expression on islet $\beta$ cells to limit T cell function during autoimmune diabetes. Scientific Reports 8 8295. (https://doi.org/10.1038/s41598-018-26471-9)

Panzer JK, Hiller H, Cohrs CM, Almaca J, Enos SJ, Beery M, Cechin S, Drotar DM, Weitz JR, Santini J, et al. 2020 Pancreas tissue slices from organ donors enable in situ analysis of type 1 diabetes pathogenesis. JCI Insight 5 e134525. (https://doi.org/10.1172/jci.insight.134525)

Penaranda C, Tang Q, Ruddle NH \& Bluestone JA 2010 Prevention of diabetes by FTY720-mediated stabilization of peri-islet tertiary lymphoid organs. Diabetes 59 1461-1468. (https://doi.org/10.2337/ db09-1129)

Phelps EA, Cianciaruso C, Michael IP, Pasquier M, Kanaani J, Nano R, Lavallard V, Billestrup N, Hubbell JA \& Baekkeskov S 2016 Aberrant accumulation of the diabetes autoantigen GAD65 in Golgi membranes https://joe.bioscientifica.com

https://doi.org/10.1530/JOE-21-0358 (c) 2021 Society for Endocrinology Published by Bioscientifica Ltd. Printed in Great Britain 
in conditions of ER stress and autoimmunity. Diabetes 65 2686-2699. (https://doi.org/10.2337/db16-0180)

Pugliese A, Yang M, Kusmarteva I, Heiple T, Vendrame F, Wasserfall C, Rowe P, Moraski JM, Ball S, Jebson L, et al. 2014 The Juvenile Diabetes Research Foundation Network for pancreatic organ donors with diabetes (nPOD) program: goals, operational model and emerging findings. Pediatric Diabetes 15 1-9. (https://doi.org/10.1111/pedi.12097)

Pujol-Borrell R, Todd I, Londei M, Foulis A, Feldmann M \& Bottazzo GF 1986 Inappropriate major histocompatibility complex class II expression by thyroid follicular cells in thyroid autoimmune disease and by pancreatic beta cells in type I diabetes. Molecular Biology and Medicine 3 159-165.

Pujol-Borrell R, Todd I, Doshi M, Bottazzo GF, Sutton R, Gray D, Adolf GR \& Feldmann M 1987 HLA class II induction in human islet cells by interferon-gamma plus tumour necrosis factor or lymphotoxin. Nature 326 304-306. (https://doi.org/10.1038/326304a0)

Qadir MMF, Álvarez-Cubela S, Weitz J, Panzer JK, Klein D, MorenoHernández Y, Cechin S, Tamayo A, Almaça J, Hiller H, et al. 2020 Long-term culture of human pancreatic slices as a model to study realtime islet regeneration. Nature Communications 11 3265. (https://doi. org/10.1038/s41467-020-17040-8)

Richardson SJ \& Morgan NG 2018 Enteroviral infections in the pathogenesis of type 1 diabetes: new insights for therapeutic intervention. Current Opinion in Pharmacology 43 11-19. (https://doi. org/10.1016/j.coph.2018.07.006)

Richardson SJ, Willcox A, Bone AJ, Foulis AK \& Morgan NG 2009 The prevalence of enteroviral capsid protein vp1 immunostaining in pancreatic islets in human type 1 diabetes. Diabetologia 52 1143-1151. (https://doi.org/10.1007/s00125-009-1276-0)

Richardson SJ, Leete P, Bone AJ, Foulis AK \& Morgan NG 2013 Expression of the enteroviral capsid protein VP1 in the islet cells of patients with type 1 diabetes is associated with induction of protein kinase $\mathrm{R}$ and downregulation of Mcl-1. Diabetologia 56 185-193. (https://doi. org/10.1007/s00125-012-2745-4)

Richardson SJ, Rodriguez-Calvo T, Gerling IC, Mathews CE, Kaddis JS, Russell MA, Zeissler M, Leete P, Krogvold L, Dahl-Jorgensen K, et al. 2016 Islet cell hyperexpression of HLA class I antigens: a defining feature in type 1 diabetes. Diabetologia 59 2448-2458. (https://doi.org/10.1007/ s00125-016-4067-4)

Røder ME, Knip M, Hartling SG, Karjalainen J, Akerblom HK \& Binder C 1994 Disproportionately elevated proinsulin levels precede the onset of insulin-dependent diabetes mellitus in siblings with low first phase insulin responses. The Childhood Diabetes in Finland Study Group. Journal of Clinical Endocrinology and Metabolism 79 1570-1575. (https:// doi.org/10.1210/jcem.79.6.7989457)

Rodriguez-Calvo T, Ekwall O, Amirian N, Zapardiel-Gonzalo J \& Von Herrath MG 2014 Increased immune cell infiltration of the exocrine pancreas: a possible contribution to the pathogenesis of type 1 diabetes. Diabetes 63 3880-3890. (https://doi.org/10.2337/db14-0549)

Rodriguez-Calvo T, Suwandi JS, Amirian N, Zapardiel-Gonzalo J, Anquetil F, Sabouri S \& Von Herrath MG 2015 Heterogeneity and lobularity of pancreatic pathology in type 1 diabetes during the prediabetic phase. Journal of Histochemistry and Cytochemistry 63 626-636. (https://doi. $\operatorname{org} / 10.1369 / 0022155415576543)$

Rodriguez-Calvo T, Zapardiel-Gonzalo J, Amirian N, Castillo E, Lajevardi Y, Krogvold L, Dahl-Jorgensen K \& Von Herrath MG 2017 Increase in pancreatic proinsulin and preservation of beta cell mass in autoantibody positive donors prior to type 1 diabetes onset. Diabetes 66 1334-1345. (https://doi.org/10.2337/db16-1343)

Rodriguez-Calvo T, Chen YC, Verchere CB, Haataja L, Arvan P, Leete P, Richardson SJ, Morgan NG, Qian WJ, Pugliese A, et al. 2021 Altered $\beta$-cell prohormone processing and secretion in type 1 diabetes. Diabetes 70 1038-1050. (https://doi.org/10.2337/dbi20-0034)

Ross JJ, Wasserfall CH, Bacher R, Perry DJ, Mcgrail K, Posgai AL, Dong X, Muir A, Li X, Campbell-Thompson M, et al. 2021 Exocrine pancreatic enzymes are a serological biomarker for type 1 diabetes staging and pancreas size. Diabetes 70 944-954. (https://doi.org/10.2337/db200995)

Russell MA, Redick SD, Blodgett DM, Richardson SJ, Leete P, Krogvold L, Dahl-Jørgensen K, Bottino R, Brissova M, Spaeth JM, et al. 2019 HLA class II antigen processing and presentation pathway components demonstrated by transcriptome and protein analyses of islet $\beta$-cells from donors with type 1 diabetes. Diabetes 68 988-1001. (https://doi. org/10.2337/db18-0686)

Sherr JL, Ghazi T, Wurtz A, Rink L \& Herold KC 2014 Characterization of residual beta cell function in long-standing type 1 diabetes. Diabetes/ Metabolism Research and Reviews 30 154-162. (https://doi.org/10.1002/ dmrr.2478)

Sherry NA, Tsai EB \& Herold KC 2005 Natural history of \{beta\}-cell function in type 1 diabetes. Diabetes 54 (Supplement 2) S32-S39. (https://doi org/10.2337/diabetes.54.suppl_2.s32)

Shields BM, Mcdonald TJ, Oram R, Hill A, Hudson M, Leete P, Pearson ER, Richardson SJ, Morgan NG, Hattersley AT, et al. 2018 C-peptide decline in type 1 diabetes has two phases: an initial exponential fall and a subsequent stable phase. Diabetes Care 41 1486-1492. (https://doi. org/10.2337/dc18-0465)

Simeonovic CJ, Popp SK, Starrs LM, Brown DJ, Ziolkowski AF, Ludwig B, Bornstein SR, Wilson JD, Pugliese A, Kay TWH, et al. 2018 Loss of intra-islet heparan sulfate is a highly sensitive marker of type 1 diabetes progression in humans. PLoS ONE 13 e0191360. (https://doi. org/10.1371/journal.pone.0191360)

Sims EK, Chaudhry Z, Watkins R, Syed F, Blum J, Ouyang F, Perkins SM, Mirmira RG, Sosenko J, Dimeglio LA, et al. 2016 Elevations in the fasting serum proinsulin-to-C-peptide ratio precede the onset of type 1 diabetes. Diabetes Care 39 1519-1526. (https://doi.org/10.2337/dc152849)

Sims EK, Evans-Molina C, Tersey SA, Eizirik DL \& Mirmira RG 2018 Biomarkers of islet beta cell stress and death in type 1 diabetes. Diabetologia 61 2259-2265. (https://doi.org/10.1007/s00125-018-4712-1)

Sims EK, Syed F, Nyalwidhe J, Bahnson HT, Haataja L, Speake C, Morris MA, Balamurugan AN, Mirmira RG, Nadler J, et al. 2019 Abnormalities in proinsulin processing in islets from individuals with longstanding T1D. Translational Research 213 90-99. (https://doi.org/10.1016/j. trsl.2019.08.001)

Skyler JS 2015 Prevention and reversal of type 1 diabetes - past challenges and future opportunities. Diabetes Care 38 997-1007. (https://doi. org/10.2337/dc15-0349)

Smeets S, De Paep DL, Stangé G, Verhaeghen K, Van Der Auwera B, Keymeulen B, Weets I, Ling Z, In't Veld P \& Gorus F 2021 Insulitis in the pancreas of non-diabetic organ donors under age 25 years with multiple circulating autoantibodies against islet cell antigens. Virchows Archiv 479 295-304. (https://doi.org/10.1007/s00428-021-03055-z)

Steffes MW, Sibley S, Jackson M \& Thomas W 2003 Beta-cell function and the development of diabetes-related complications in the diabetes control and complications trial. Diabetes Care 26 832-836. (https://doi. org/10.2337/diacare.26.3.832)

Thomas NJ, Jones SE, Weedon MN, Shields BM, Oram RA \& Hattersley AT 2018 Frequency and phenotype of type 1 diabetes in the first six decades of life: a cross-sectional, genetically stratified survival analysis from UK Biobank. Lancet: Diabetes and Endocrinology 6 122-129. (https://doi.org/10.1016/S2213-8587(17)30362-5)

Truyen I, De Pauw P, Jørgensen PN, Van Schravendijk C, Ubani O, Decochez K, Vandemeulebroucke E, Weets I, Mao R, Pipeleers DG, et al. 2005 Proinsulin levels and the proinsulin:c-peptide ratio complement autoantibody measurement for predicting type 1 diabetes. Diabetologia 48 2322-2329. (https://doi.org/10.1007/s00125005-1959-0)

Tsai EB, Sherry NA, Palmer JP \& Herold KC 2006 The rise and fall of insulin secretion in type 1 diabetes mellitus. Diabetologia 49 261-270. (https:// doi.org/10.1007/s00125-005-0100-8)

Van Dalem A, Demeester S, Balti EV, Keymeulen B, Gillard P, Lapauw B, De Block C, Abrams P, Weber E, Vermeulen I, et al. 2016 Prediction of https://joe.bioscientifica.com

https://doi.org/10.1530/JOE-21-0358 (c) 2021 Society for Endocrinology Published by Bioscientifica Ltd. Printed in Great Britain 
impending type 1 diabetes through automated dual-label measurement of proinsulin:C-peptide ratio. PLOS ONE 11 e0166702. (https://doi. org/10.1371/journal.pone.0166702)

Virostko J, Hilmes M, Eitel K, Moore DJ \& Powers AC 2016 Use of the electronic medical record to assess pancreas size in type 1 diabetes. PLoS ONE 11 e0158825. (https://doi.org/10.1371/journal.pone.0158825)

Virostko J, Williams J, Hilmes M, Bowman C, Wright JJ, Du L, Kang H, Russell WE, Powers AC \& Moore DJ 2019 Pancreas volume declines during the first year after diagnosis of type 1 diabetes and exhibits altered diffusion at disease onset. Diabetes Care 42 248-257. (https:// doi.org/10.2337/dc18-1507)

von Meyenburg H 1940 Über 'insulitis' bei diabetes. Schweizerische Medizinische Wochenschrift 21 554-557.

Wang L, Lovejoy NF \& Faustman DL 2012 Persistence of prolonged C-peptide production in type 1 diabetes as measured with an ultrasensitive C-peptide assay. Diabetes Care 35 465-470. (https://doi. org/10.2337/dc11-1236)

Wasserfall C, Nick HS, Campbell-Thompson M, Beachy D, Haataja L, Kusmartseva I, Posgai A, Beery M, Rhodes C, Bonifacio E, et al. 2017
Persistence of pancreatic insulin mRNA expression and proinsulin protein in type 1 diabetes pancreata. Cell Metabolism 26 568.e3-575.e3. (https://doi.org/10.1016/j.cmet.2017.08.013)

Westermark GT, Krogvold L, Dahl-Jørgensen K \& Ludvigsson J 2017 Islet amyloid in recent-onset type 1 diabetes-the $\mathrm{DiViD}$ study. Upsala Journal of Medical Sciences 122 201-203. (https://doi.org/10.1080/03009734.20 17.1359219)

Wiberg A, Granstam A, Ingvast S, Harkonen T, Knip M, Korsgren O \& Skog O 2015 Characterization of human organ donors testing positive for type 1 diabetes-associated autoantibodies. Clinical and Experimental Immunology 182 278-288. (https://doi.org/10.1111/cei.12698)

Willcox A, Richardson SJ, Bone AJ, Foulis AK \& Morgan NG 2009 Analysis of islet inflammation in human type 1 diabetes. Clinical and Experimental Immunology 155 173-181. (https://doi.org/10.1111/j.13652249.2008.03860.x)

Wrenshall GA, Bogoch A \& Ritchie RC 1952 Extractable insulin of pancreas; correlation with pathological and clinical findings in diabetic and nondiabetic cases. Diabetes 1 87-107. (https://doi.org/10.2337/ diab.1.2.87)

Received in final form 4 November 2021

Accepted 9 November 2021

Accepted Manuscript published online 10 November 2021 (c) 2021 Society for Endocrinology Published by Bioscientifica Ltd.
Printed in Great Britain 